\title{
Preparation, Structural Analysis and Reactivity Studies of Phosphenium Dications
}

\author{
Madelyn Qin Yi Tay, ${ }^{\ddagger, \dagger}$ Gordana Ilić, ${ }^{\ddagger}$ Ulrike Werner-Zwanziger, $*, \$$ Yunpeng Lu, ${ }^{\ddagger}$ Rakesh \\ Ganguly, ${ }^{\ddagger}$ Louis Ricard ${ }^{\dagger}$ Gilles Frison, ${ }^{*, \dagger}$ Duncan Carmichael, ${ }^{* \dagger}$ Dragoslav Vidović ${ }^{*, \ddagger}$ \\ * School of Physical and Matematical Sciences, Division of Chemistry and Biological Chemistry, Nanyang \\ Technological University, 21 Nanyang Link, Singapore, 637371 \\ ${ }^{\dagger}$ LCM, CNRS, Ecole polytechnique, Université Paris-Saclay, 91128 Palaiseau, France \\ ${ }^{\S}$ Department of Chemistry, Dalhousie University, 6274 Coburg Road, Halifax, NS, B3H 4R2, Canada \\ Supporting Information Placeholder
}

\begin{abstract}
This work expands on the recent synthesis and reactivity of a two-coordinate $\mathrm{P}(\mathrm{III})$-containing dication $\left[\left(\left(\mathrm{Ph}_{3} \mathrm{P}\right)_{2} \mathrm{C}\right) \mathrm{P}\left(\mathrm{N}^{\mathrm{i}} \mathrm{Pr}_{2}\right)\right]^{2+}\left(\mathbf{3 a}^{2+}\right)$. Two additional dications of general formula $\left[\left(\left(\mathrm{RPh}_{2} \mathrm{P}\right)_{2} \mathrm{C}\right) \mathrm{P}\left(\mathrm{NR}_{2}\right)^{2}\right]^{2+}\left(\mathbf{3 b}^{2+}: \mathrm{R}^{2} \mathbf{1}_{2}\left(\mathrm{CH}_{2}\right)_{3}\right.$, $\mathrm{R}^{\prime}={ }^{\mathrm{i}} \mathrm{Pr} ; \mathbf{3 c}^{2+}: \mathrm{R}=\mathrm{Ph}, \mathrm{R}^{\prime}=\mathrm{Cy}$ ) have been prepared. Solution and solid state ${ }^{31} \mathrm{P}$ NMR isotropic shifts for this dication class were observed around $360 \mathrm{ppm}$. Except for $[3 \mathbf{a}]\left[\mathrm{SbF}_{6}\right]_{2}$, the ${ }^{31} \mathrm{P} \mathrm{CP} / \mathrm{MAS}$ NMR spectra reveal a high degree of structural disorder around the dicationic site in the solid state. Surprisingly, the synthesis of dication $\mathbf{3} \mathbf{a}^{\mathbf{2 +}}$ was only possible in the presence of $\mathrm{AlCl}_{4}^{-}, \mathrm{SbF}_{6}^{-}$and substituted tetraarylborates while the use of $\mathrm{ClO}_{4}^{-}, \mathrm{OTf}^{-}, \mathrm{BF}_{4}^{-}, \mathrm{PF}_{6}^{-}$and $\mathrm{BPh}_{4}^{-}$resulted in complex product mixtures. Single crystal X-ray analysis of dications $\mathbf{3 a}^{2+}$ and $\mathbf{3} \mathbf{c}^{2+}$ suggested an $4 \pi$ allyl-like structure for the central CPN fragment, and this has been supported through detailed theoretical investigations. Initial reactivity studies between dications $3 \mathbf{a}^{2+} / \mathbf{3 c}^{\mathbf{2 +}}$ and $\mathrm{PMe}_{3}$ show an equilibrium between the free dication and the target adduct. Furthermore, $\mathbf{3} \mathbf{a}^{2+}$ has been shown to be capable of $\mathrm{O}-\mathrm{H}$ bond activation using water and methanol, and polymerizes THF when dissolved in this solvent.
\end{abstract}

\section{INTRODUCTION}

Two coordinate phosphorus(III)-containing cations, also known as phosphenium ions, have attracted much interest over recent years because they often contain an N-P-N fragment (A, Figure 1) that is isolobal to the N-C-N fragment found in "Arduengo"-N-heterocyclic carbenes (NHCs). ${ }^{1}$ However, unlike NHCs, phosphenium cations are poor $\sigma$ donors and good $\pi$-acceptors. ${ }^{2}$ Introducing an additional positive charge to these species should lower the LUMO, thus creating better $\pi$-acceptors and more reactive P-centred Lewis acids. These cations can be clearly distinguished from a class of polycationic phosphorus(III)-containing compounds that have coordinatively saturated phosphorus atoms, ${ }^{3}$ and which strongly resemble neutral phosphines in terms of their structural features and reactivity patterns (B and $\mathbf{C}$, Figure 1) ${ }^{4}$ As noted above, previous examples of stable monocationic phosphenium species (A) have often contained two amino ligands, because of the ability of these substituents to donate electron density to the formally vacant out-of-plane $\mathrm{p}_{z}$ orbital on the central phosphorus. It was our assumption that the synthesis of a two-coordinate unsaturated P(III)containing dication (D, Figure 1) would require an exceptionally strong electron-donor neutral ligand to compensate for the increased electron depletion in such species, in addition to the commonly used amino substituent. Carbodiphosphoranes, ${ }^{5}$ (Figure 2) have shown to be ideal candidates for this particular purpose because these neutral ligands have been used to stabilize several exceptionally electron deficient main group species. ${ }^{6}$ These "carbones" (as exemplified by $\left.\left(\mathrm{Ph}_{3} \mathrm{P}\right)_{2} \mathrm{C}, \mathbf{1 a}\right)^{7}$ were one of the earliest reported classes of bent allenes and, over the years, other reported examples have included carbodicarbenes, as well as the heavier $\mathrm{Si}$ and $\mathrm{Ge}$ analogues of carbones. ${ }^{8,9}$ According to theoretical investigations, the central atom of these compounds has two lone pairs, of $\sigma$ and $\pi$ symmetry, and this potentially allows them to act as four-electron donors (Figure 2$) ;^{5}$ the exceptional electron donation capacity of 1a was considered to be a determinant factor in the isolation of the first dicationic phosphenium ion $\left[\left(\mathrm{PPh}_{3}\right)_{2} \mathrm{C}-\mathrm{P}-\mathrm{N}^{\mathrm{i}} \mathrm{Pr}_{2}\right]^{2+}$ $\left(3 \mathbf{a}^{2+}\right){ }^{6 c}$ In this report, we use solid state NMR and computational analyses to examine the influence of both the substituents and the counterion on the stability and reactivity of this kind of dication, with the objective of better delineating the bonding features that confer stability on their cores. Finally, reactivity studies involving coordination chemistry, controlled $\mathrm{O}-\mathrm{H}$ bond cleavage and solvent polymerization are also given. ${ }^{6 \mathrm{~d}}$ 


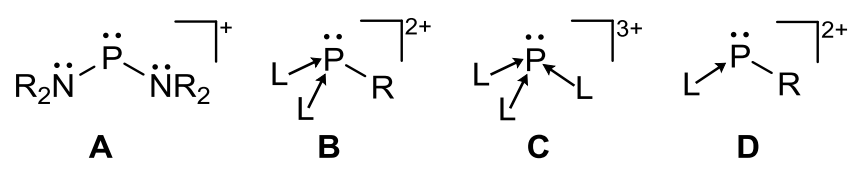

Figure 1. Phosphenium cation (A), coordinatively saturated polycationic P(III)-containing species (B and C) and coordinatively unsaturated phosphenium ion (D).

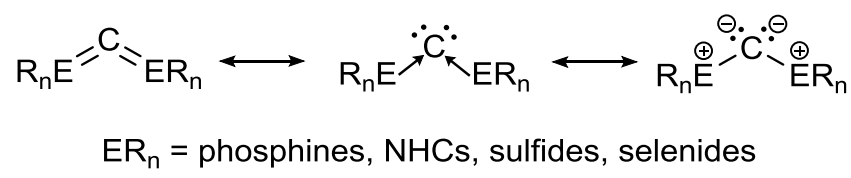

Figure 2. Commonly used structural representations for carbone molecules.

\section{RESULTS AND DISCUSSION}

$\underline{\text { Preparation }}$

The synthesis of the target dications was achieved via the two-step process described in Scheme 1. The first step involved the preparation of the monocationic precursors, $\left.\left[\left(\mathrm{RPh}_{2} \mathrm{P}\right)_{2} \mathrm{CP}(\mathrm{Cl}) \mathrm{NR}_{2}\right)\right][\mathrm{Cl}]\left([\mathbf{2 a}][\mathrm{Cl}]: \mathrm{R}=\mathrm{Ph}, \mathrm{R}^{\prime}={ }^{i} \mathrm{Pr}\right.$; [2b] $[\mathrm{Cl}]: \mathrm{R}=1 / 2\left(\mathrm{CH}_{2}\right)_{3}, \mathrm{R}^{\prime}={ }^{i} \mathrm{Pr} ;[\mathbf{2 c}][\mathrm{Cl}]: \mathrm{R}=\mathrm{Ph}, \mathrm{R}^{\prime}=\mathrm{Cy}$; [2d] $\left.[\mathrm{Cl}]: \mathrm{R}=1 / 2\left(\mathrm{CH}_{2}\right)_{3}, \mathrm{R}^{\prime}=\mathrm{Cy}\right)$ through the addition of a carbone ligand $\left(\mathbf{1 a}\right.$ or $\left(\mathrm{Ph}_{2} \mathrm{P}\left(\mathrm{CH}_{2}\right)_{3} \mathrm{PPh}_{2}\right) \mathrm{C}$, 1b) to a benzene solution containing excess of the corresponding aminodichlorophosphine $\left(\mathrm{R}_{2}{ }_{2} \mathrm{NPCl}_{2} ; \mathrm{R}{ }^{\prime}={ }^{\mathrm{i}} \mathrm{Pr}\right.$ or $\left.\mathrm{Cy}\right)$. The desired carbone-for-chloride exchange was observed for every target except for $[\mathbf{2 d}][\mathrm{Cl}]$, presumably because the necessary reactant combination presents greater steric constraints for $[\mathbf{2 d}]^{+}$than the other cations. Successful ligand exchange was associated with the appearance of two second order signals, a doublet $(\sim 20 \mathrm{ppm})$ and a triplet $(\sim 140 \mathrm{ppm})$, in the ${ }^{31} \mathrm{P}$ NMR spectra of the reaction mixtures. It is also noteworthy that the ${ }^{13} \mathrm{C}$ NMR spectra of the product monocations exhibit a doublet of triplets at $\sim 20 \mathrm{ppm}$ that arises from the central $\mathrm{C}$ atom of the carbone ligand.

Scheme 1. Preparation of dicationic species.

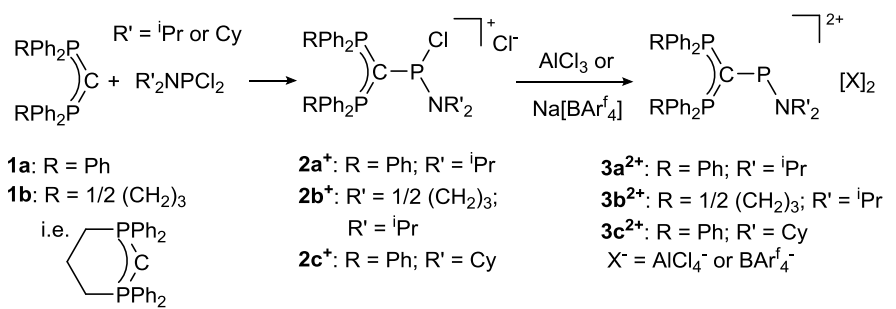

The formation of dication $[3 \mathbf{a}][\mathrm{X}]_{2}\left(\mathrm{X}=\mathrm{AlCl}_{4}{ }^{-}\right.$or $\mathrm{BAr}_{4}^{\mathrm{f}}$; $\left.\mathrm{Ar}^{\mathrm{f}}=3,5-\left(\mathrm{CF}_{3}\right)_{2}-\mathrm{C}_{6} \mathrm{H}_{3}\right)$ was achieved through the addition of 2.1 eq of either $\mathrm{AlCl}_{3}$ or $\mathrm{Na}\left[\mathrm{BAr}_{4}^{\mathrm{f}}\right]$ to a DCM solution containing [1a][Cl] ${ }^{6 \mathrm{c}}$ The clearest evidence for the formation of the two-coordinate dication comes from a $\delta_{\mathrm{P}}$ resonance at around $356 \mathrm{ppm}$; this is assigned to the central $\mathrm{P}$ atom and lies more than 200ppm downfield from the analogous signal in the monocationic precursor. These $\delta_{\mathrm{P}}$ values for the

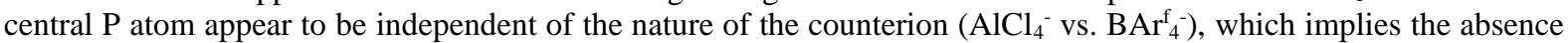
of close interion contacts in the solution state. The electron depletion associated with the newly formed dication is also associated with a marked downfield shift $(\sim 40 \mathrm{ppm})$ of the $\delta_{\mathrm{C}}$ signal assigned to the central carbon atom of the carbone ligand. Similar observations were documented in reactions between $[\mathbf{2 b}][\mathrm{Cl}] /[\mathbf{2 c}][\mathrm{Cl}]$ and the two halide abstraction reagents $\mathrm{AlCl}_{3}$ and $\mathrm{NaBAr}$.

X-ray

The structures of several monocationic precursors ([2a] $\left[\mathrm{AlCl}_{4}\right]$ and $\left.[\mathbf{2 c}]\left[\mathrm{BAr}_{4}^{\mathrm{f}}\right]\right)$ and dicationic species $\left([\mathbf{3 a}][\mathrm{X}]_{2}(\mathrm{X}\right.$ $=\mathrm{AlCl}_{4}{ }^{-}$or $\mathrm{BAr}_{4}^{-}$) and $\left.[3 \mathbf{c}]\left[\mathrm{AlCl}_{4}\right]_{2}\right)$ ) have been elucidated by single crystal $\mathrm{x}$-ray diffraction (Figure 3 ). The monocations adopt a classical pyramidal geometry around the central phosphorus; the sum of the bond angles around

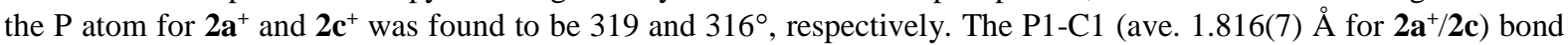
distance for the monocations is slightly shorter than the average P-C observed for several NHC-stabilized phosphenium 


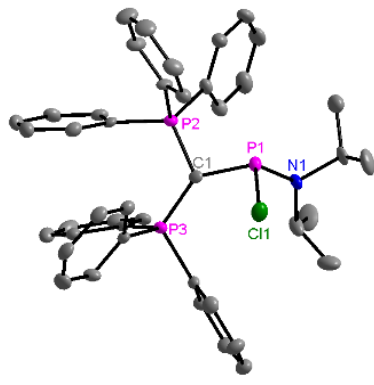

$2 \mathbf{a}^{+}$

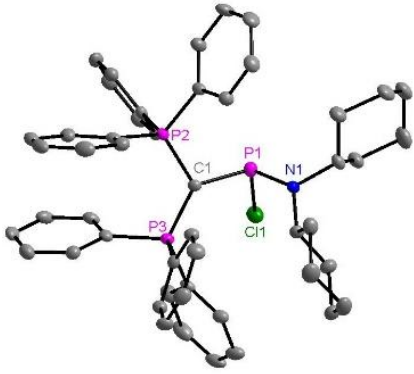

$2 c^{+}$

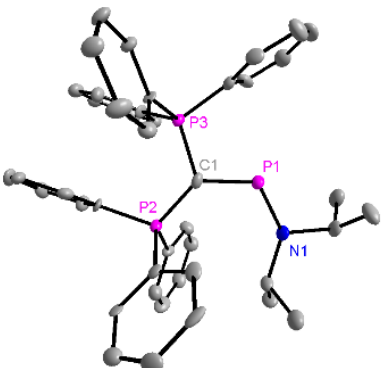

$3 \mathbf{a}^{2+}$

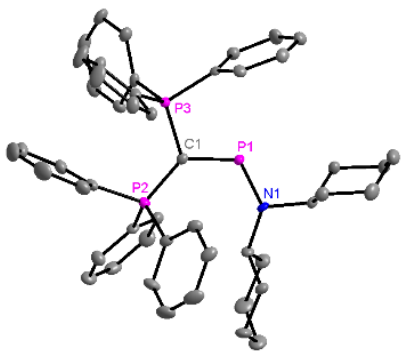

$3 c^{2+}$

Figure 3. Molecular structures for $[\mathbf{2 a}]\left[\mathrm{AlCl}_{4}\right],[\mathbf{2 c}]\left[\mathrm{BAr}_{4}^{\mathrm{f}}\right],[\mathbf{3 a}][\mathrm{X}]_{2}\left(\mathrm{X}=\mathrm{AlCl}_{4}^{-}\right.$or $\left.\mathrm{BAr}_{4}{ }^{-}\right)$and $[\mathbf{3 c}]\left[\mathrm{AlCl}_{4}\right]_{2}$. Thermal ellipsoids are shown at 50\% probability. The hydrogen atoms, counter anion(s) and/or second independent unit are omitted for clarity. Selected bond lengths $(\AA)$ and angles $\left(^{\circ}\right)$ - the values in the parenthesis are of the second asymmetric unit while for $\mathbf{3 \mathbf { a } ^ { 2 + }}$ the additional set of parameters is for [3a] $\left[\mathrm{BAr}^{\mathrm{f}} 4\right.$ ]. 2a ${ }^{+}$: $\mathrm{P}(1)-\mathrm{C}(1), 1.812(5)$ (1.815(6)); $\mathrm{P}(1)-\mathrm{N}(1), 1.660(4)$ (1.652(5)); $\mathrm{P}(1)-\mathrm{Cl}(1), 2.173(2)$ (2.178(2)); $\mathrm{N}(1)-\mathrm{P}(1)-\mathrm{C}(1)$,

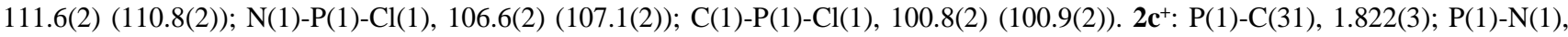
1.655(3); $\mathrm{P}(1)-\mathrm{Cl}(1), 2.143(1) ; \mathrm{N}(1)-\mathrm{P}(1)-\mathrm{C}(31), 111.9(1) ; \mathrm{N}(1)-\mathrm{P}(1)-\mathrm{Cl}(1), 103.5(1) ; \mathrm{C}(1)-\mathrm{P}(1)-\mathrm{Cl}(1), 103.5(1) .3 \mathbf{a}^{2+}: \mathrm{P}(1)-\mathrm{C}(1)$,

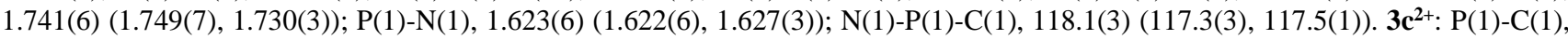
$1.736(3)(1.737(3)) ; \mathrm{P}(1)-\mathrm{N}(1), 1.624(3)$ (1.620(3)); N(1)-P(1)-C(1), 118.2(2) (118.6(2)).

cations (ave. 1.840(8) $\AA$ ). ${ }^{4 b, 10}$ Also, the P1-N1 bond distance (ave. 1.656(5) $\AA$ for $2 \mathbf{a}^{+} / 2 \mathbf{c}^{+}$) is slightly longer than the P$\mathrm{N}$ distance observed for a couple of dialkylaminodichlorophosphines (ave. 1.632(2) $\AA$ ). ${ }^{11}$ These observation are probably due to the increased nucleophilic nature of the carbone substituent with respect to, for example, the NHCs. Removal of the chloride ligand to form the dications was accompanied by the shortening of the P1-C1 (ave. 1.739(5) $\AA$ for $3 \mathbf{a}^{2+} / \mathbf{3 c}^{2+}$ ) and P1-N1 (ave. 1.623(5) $\AA$ for $3 \mathbf{a}^{2+} / \mathbf{3 c}^{2+}$ ) bond distances. These bond contractions are presumed to reflect increased electron donation from both amine and carbone substituents to the central phosphorus. The fact that a): both the $\mathrm{N}$ and $\mathrm{C}$ atoms adjacent to the central $\mathrm{P}$ possess $\pi$-symmetry lone pairs and $\mathrm{b}$ ): the $\mathrm{C}_{2} \mathrm{NPCP}_{2}$ fragment is virtually planar means that it is not difficult to envision electron density "flow" from the amino and carbone substituents into the formally vacant $\mathrm{p}_{\mathrm{z}}$ orbital on the central $\mathrm{P}$ that is created upon abstraction of the chloride. Additionally, the dication P-N $(\sim 1.62 \AA)^{12}$ and P-C $(\sim 1.74 \AA)^{13}$ distances are somewhere between the values for single and double bonds, which also implies $4 \pi$ allyl-like characteristics for the CPN fragment. This bonding description for the CPN fragment is explored further in detailed theoretical investigations below.

Scheme 2. The synthesis of $3 \mathrm{a}^{2+}$ in the presence of various counterions.

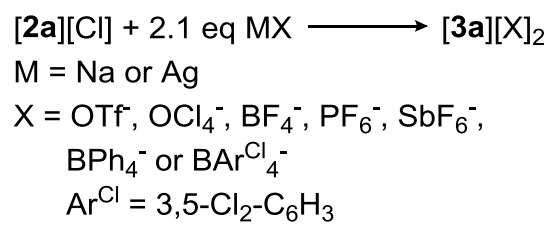

\section{Counterion dependence}

$\mathrm{AlCl}_{4}^{-}$anions have been shown to sometimes interfere with the reactivity of $3 \mathbf{a}^{2+}$ (see below), and the recrystallization of dications having $\mathrm{BAr}_{4}{ }^{-}$counteranions has proved to be somewhat difficult, so we set out to explore whether a different anion could be employed. It was assumed that a wide variety of anions could be used for the preparation of these dications, given that they are stable in the presence of both coordinating $\left(\mathrm{AlCl}_{4}^{-}\right)$and also large, weakly coordinating $\left(\mathrm{BAr}_{4}^{\mathrm{f}}{ }^{-}\right)$counterions. However, we investigated the synthesis of $3 \mathbf{a}^{2+}$ only in the presence of OTf $\left(\mathrm{Tf}=\mathrm{O}_{2} \mathrm{SCF}_{3}\right), \mathrm{ClO}_{4}^{-}, \mathrm{BF}_{4}^{-}, \mathrm{PF}_{6}^{-}, \mathrm{SbF}_{6}^{-}, \mathrm{BPh}_{4}^{-}$and $\mathrm{BAr}_{4}^{-\mathrm{Cl}_{-}^{-}}\left(\mathrm{Ar}^{\mathrm{Cl}}=3,5-\mathrm{Cl}_{2}-\mathrm{C}_{6} \mathrm{H}_{3}\right)$, through reacting [2a] $[\mathrm{Cl}]$ with 2.1 equiv of the corresponding anion sources (Scheme 2). Unexpectedly, $\mathbf{3 a}^{2+}$ dications could only be isolated in the presence of $\mathrm{SbF}_{6}^{-}$and $\mathrm{BAr}_{4}^{-}$, with reactions involving the other anions usually resulting in complex mixtures of unidentified products. ${ }^{14}$ Early reactivity studies using $\mathbf{3 \mathbf { a } ^ { 2 + }}$ (see below) suggest that this dication could be very oxophilic and consequently quite destructive towards oxygen-containing anions and/or substrates. Similar conclusions might be formulated with regards to its fluorophilicity: the results tend to suggest that the $\mathbf{3} \mathbf{a}^{\mathbf{2 +}}$ dication has a greater fluoride anion affinity than $\mathrm{BF}_{3}$ and $\mathrm{PF}_{5}$, but not than $\mathrm{SbF}_{5}$, with the result that $\mathbf{3 a}^{2+}$ decomposes in the presence of $\mathrm{BF}_{4}{ }^{-}$and $\mathrm{PF}_{6}^{-}$ anions. Comparable observations have been reported during the synthesis of gallium cations. ${ }^{15}$ It is also noteworthy that 
(i) $\mathrm{AgSbF}_{6}$ was the preferred source for this particular anion, because the reaction proceeded much faster rather than with, for example, $\mathrm{NaSbF}_{6}$ and (ii) the presence of $\mathrm{SbF}_{6}-$ did not interfere with the reactivity of $\mathbf{3 a}^{2+}$ (see below).

Interestingly, all dicationic compounds $[3 \mathbf{a}][\mathrm{X}]_{2}\left(\mathrm{X}=\mathrm{AlCl}_{4}, \mathrm{BAr}_{4}{ }_{4} \text { and } \mathrm{BAr}_{4}^{\mathrm{f}}\right)^{16}$ were yellow in the solid state except for $[3 \mathbf{a}]\left[\mathrm{SbF}_{6}\right]_{2}$, which was colorless. It is postulated that the close interion contacts seen in the crystal structure of [3a] $\left[\mathrm{SbF}_{6}\right]_{2}$ disrupt the $4 \pi$ allyl-like system of the C-P-N fragment and consequently quench the normal yellow color.

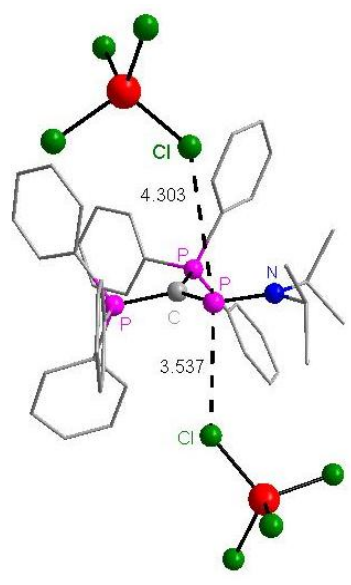

$[3 a]\left[\mathrm{AlCl}_{4}\right]_{2}$

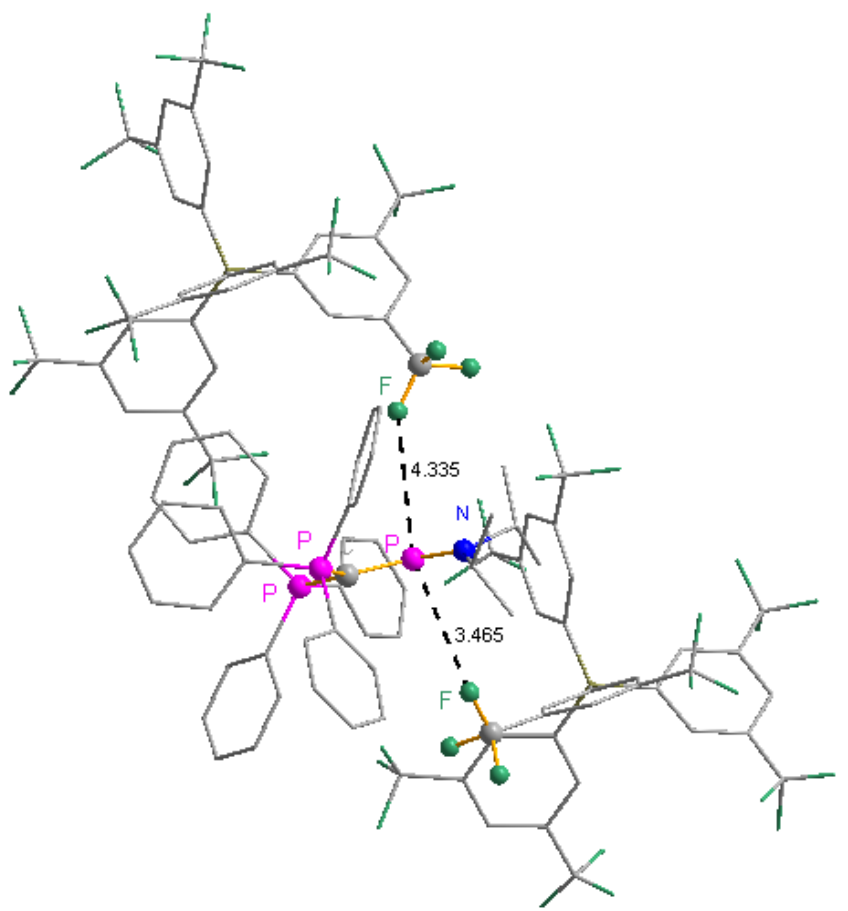

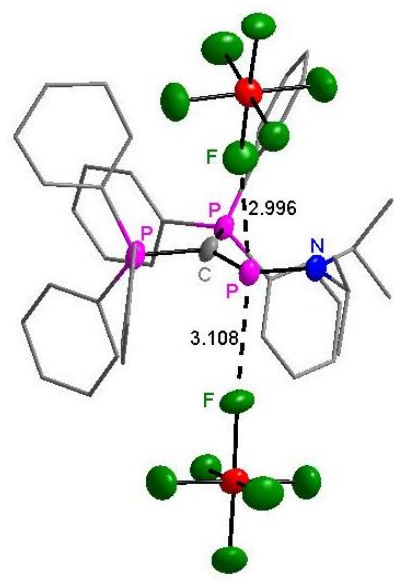

$[3 a]\left[\mathrm{SbF}_{6}\right]_{2}$

$[3 a]\left[\mathrm{BAr}_{4}^{\mathrm{f}}\right]_{2}$

Figure 4. Close interion contacts for $[\mathbf{3 a}]\left[\mathrm{AlCl}_{4}\right]_{2},[3 \mathbf{a}]\left[\mathrm{SbF}_{6}\right]_{2}$ and $[\mathbf{3 a}]\left[\mathrm{BAr}_{4}\right]_{2}$. 
More evidence for this hypothesis was gained upon dissolving [3a] $\left[\mathrm{SbF}_{6}\right]_{2}$ in $\mathrm{DCM}$ which, in regenerating its usual yellow color, clearly suggests that the $\mathrm{P} \cdots \mathrm{F}$ close contact(s) observed for $[3 \mathbf{3 a}]\left[\mathrm{SbF}_{6}\right]_{2}$ are more pronounced in the crystal than in solution. Careful examination of the solid state structures of $[\mathbf{3 a}]\left[\mathrm{BAr}_{4}^{\mathrm{f}}\right]_{2},[\mathbf{3 a}]\left[\mathrm{AlCl}_{4}\right]_{2}$, and $[\mathbf{3 a}]\left[\mathrm{SbF}_{6}\right]_{2}(\mathrm{Figure}$ 4) revealed (i) no interaction between $\mathrm{BAr}_{4}^{\mathrm{f}}$ and the dication, where both $\mathrm{P} \cdots \mathrm{F}$ contacts $(3.46$ and $4.33 \AA$ ) were outside the sum for van der Waals (vdW) radii for $\mathrm{P}$ and $\mathrm{F}(3.36 \AA),{ }^{17}$ (ii) minimal interion interactions for [3a] $\left[\mathrm{AlCl}_{4}\right]_{2}$, where only one $\mathrm{P}{ }^{\cdots} \mathrm{Cl}$ interaction of $3.54 \AA$ lies within for the sum of the van der Waals (vdW) radii for $\mathrm{P}$ and $\mathrm{Cl}(3.72 \AA)$ and (iii) substantial $\mathrm{P} \cdots \mathrm{F}$ (anion) interactions for $[3 \mathbf{a}]\left[\mathrm{SbF}_{6}\right]_{2}$, where two $\mathrm{P} \cdots \mathrm{F}$ contacts $(3.00$ and $3.10 \AA$ ) were well with the sum of the vdW radii for $\mathrm{P}$ and $\mathrm{F}\left(3.36 \AA\right.$ ). However, solution state cation-anion interactions for $[\mathbf{3 a}]_{0}\left[\mathrm{SbF}_{6}\right]_{2}$ and the other dicationic systems seem to be minimal or even non-existent, given that the $\delta_{\mathrm{P}}$ value of $\sim 356 \mathrm{ppm}$ for the central $\mathrm{P}$ for $3 \mathbf{a}^{2+}$ was independent of the nature of the counterion $\left(\mathrm{AlCl}_{4}^{-}, \mathrm{SbF}_{6}^{-}, \mathrm{BAr}_{4}^{-\mathrm{Cl}^{-}}, \mathrm{BAr}_{4}^{-}\right)$.
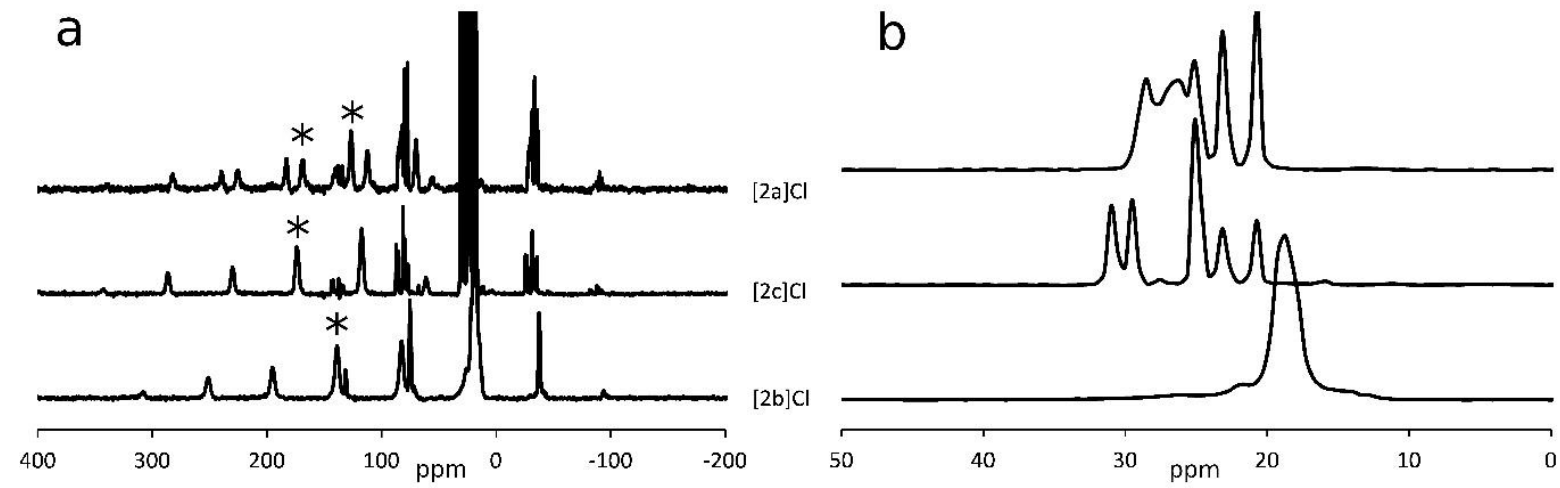

Figure 5. ${ }^{31} \mathrm{P}$ CP/MAS NMR spectra of the monocationic precursors, specifically of [2a] (top), [2c] (center) and [2b] (bottom) with $\mathrm{Cl}^{-}$ counter ions taken at $9 \mathrm{kHz}$ spinning speed. Isotropic peaks are indicated with asterisks in (a). Section (b) enlarges the spectral region between 0 to $50 \mathrm{ppm}$ and shows only isotropic shift resonances.
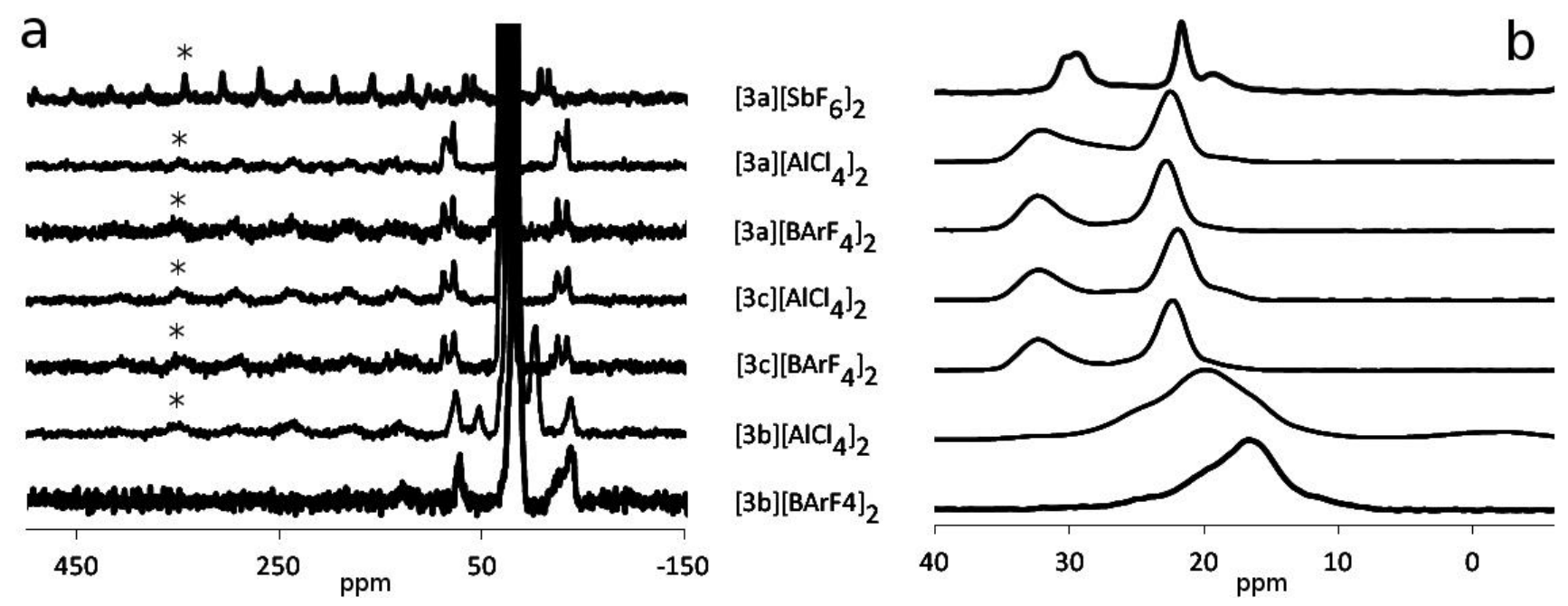

Figure 6. ${ }^{31} \mathrm{P}$ CP/MAS NMR spectra of the dicationic products as indicated by the labels. Isotropic peaks are indicated with asterisks in (a). Section (b) highlights the spectral region of the carbodiphosphorane resonances and shows only isotropic shift resonances. The spectra were acquired at $9 \mathrm{kHz}$ MAS spinning rate, except for the top spectra of $[3 \mathbf{3 a}]\left[\mathrm{SbF}_{6}\right]_{2}$, which was taken at $6 \mathrm{kHz}$. 


\section{${ }^{31} \mathrm{P}$ Solid State NMR Spectroscopy}

${ }^{31} \mathrm{P}$ cross-polarization (CP)/ magic angle spinning (MAS) NMR spectra are shown in Figures 5 and 6 over the entire observed chemical shift range (a) and enlarged (b). All shown spectra were acquired at $9 \mathrm{kHz}$ MAS spinning frequency, except for the top spectra in Figure $6\left(\mathrm{a}\right.$ and $\mathrm{b}$ ) of $[3 \mathbf{3 a}]\left[\mathrm{SbF}_{6}\right]_{2}$, which were taken at $6 \mathrm{kHz}$. Comparisons between the spectra measured at different spinning frequencies for each sample (not shown) allow the distinction between spinning sidebands and center bands, (see Table 1and Table 2). All spectra show intense features between -5 and 35 ppm and resonances further downfield (see Figures 5 and 6) with varying line widths. In solid state NMR the line widths reveals the extent of structural disorder around the observed phosphorous nucleus such as bond angle and bond length distributions. Therefore it is interesting to note that the ${ }^{31} \mathrm{P}$ CP/MAS NMR spectra of the monocations (Figure 5) are sharper than those of the dication series (Figure 6) and within the dication series the spectra of $[\mathbf{3 a}]\left[\mathrm{SbF}_{6}\right]_{2}$ are strikingly sharper than the others. Signals from the compounds with cyclic carbones, i.e. $\mathrm{C}\left(\mathrm{PPh}_{2}\right)_{2} \mathrm{C}_{3} \mathrm{H}_{6},\left(\mathbf{2 b}^{+}\right.$and $\left.\mathbf{3 b} \mathbf{b}^{2+}\right)$, are broader than those containing acyclic carbones $\left(\mathbf{2 a}^{+}, \mathbf{2} \mathbf{c}^{+}, \mathbf{3} \mathbf{a}^{2+}\right.$ and $\left.\mathbf{3} \mathbf{c}^{2+}\right)$, i.e. materials with $\mathrm{C}-\mathrm{P}\left(\mathrm{Ph}_{3}\right)_{2}$ ligands.

Assigning the resonances, the peak clusters between - $5 \mathrm{ppm}$ and $35 \mathrm{ppm}$ (Figures $5 \mathrm{~b}$ and $6 \mathrm{~b}$ ) stem from the phosphorus nuclei in the carbodiphosphorane groups, given their similarity with the solid state ${ }^{31} \mathrm{P}$ CP/MAS NMR spectra of $\left[\mathrm{HC}\left(\mathrm{PPh}_{3}\right)_{2}\right]^{+} \mathrm{Br}^{-}(23.2 \mathrm{ppm}$ and $21.2 \mathrm{ppm}$, spectra not shown, possibly present as impurity in 2a]Cl and $[\mathbf{2 c}] \mathrm{Cl})$. For compounds $[\mathbf{2 a}] \mathrm{Cl}$ and $[\mathbf{2 c}] \mathrm{Cl}$ some peak intensities come in pairs likely from two magnetically nonequivalent $\mathrm{PPh}_{3}$ groups within each carbodiphosphorane in the solid state. In contrast to the acyclic compounds, the peaks of the series containing cyclic carbones, [2b] and [3b], are disorder broadened and shifted further upfield. Interestingly within the dications, the signals in the spectra of the $[\mathbf{3 a}]\left[\mathrm{SbF}_{6}\right]_{2}$ are strikingly sharper than the others. Its phosphorane isotropic shifts at 19.3 and $21.7 \mathrm{ppm}$ resonate at frequencies, where the spectra of the other compounds, $[\mathbf{3 a}][\mathrm{X}]_{2}$ and $[\mathbf{3 c}][\mathrm{X}]_{2}\left(\mathrm{X}=\mathrm{AlCl}_{4}, \mathrm{BAr}_{4}^{\mathrm{f}}\right)$, only show shoulders. It seems that the phosphorane groups in $[3 \mathbf{3 a}]\left[\mathrm{SbF}_{6}\right]_{2}$ crystallize predominantly in configurations only occupied to a minor extent by the other materials.

Table 1. Solid state ${ }^{31} \mathrm{P}$ CP/MAS NMR isotropic chemical shift positions of all monocationic precursors.

\begin{tabular}{lll}
\hline$[\mathbf{2 a}] \mathrm{Cl}$ & {$[\mathbf{2 b}] \mathrm{Cl}$} & {$[\mathbf{2 c}] \mathrm{Cl}$} \\
$/ \mathrm{ppm}$ & $/ \mathrm{ppm}$ & $/ \mathrm{ppm}$ \\
\hline 20.7 & 18.8 & 20.7 \\
23.2 & & 23.2 \\
25.1 & & 25.1 \\
26.1 & & 29.5 \\
28.5 & & 31.0 \\
126.8 & & \\
168.8 & 139.0 & 174.2 \\
20.7 & 18.8 & 20.7 \\
\hline
\end{tabular}

Table 2. ${ }^{31} \mathbf{P}$ Solid state NMR isotropic chemical shift positions of all dicationic compounds

\begin{tabular}{cccccc}
\hline $\begin{array}{c}\mathbf{3 a}] \\
{[\mathrm{SbF}]_{2}} \\
/ \mathrm{ppm}\end{array}$ & $\begin{array}{c}{[\mathbf{3 a}]} \\
{[\mathrm{AlCl} 4]_{2}} \\
/ \mathrm{ppm}\end{array}$ & $\begin{array}{c}{[\mathbf{3 a}]^{\mathrm{f}}} \\
{\left[\mathrm{BAr}_{4}\right]_{2}} \\
/ \mathrm{ppm}\end{array}$ & $\begin{array}{c}{[\mathbf{3 c}]} \\
{\left[\mathrm{AlCl}_{4}\right]_{2}} \\
/ \mathrm{ppm}\end{array}$ & $\begin{array}{c}{[\mathbf{3 c}]^{[}} \\
{\left[\mathrm{BAr}_{4}\right]_{2}} \\
/ \mathrm{ppm}\end{array}$ & $\begin{array}{c}{[\mathbf{3 b}]^{2}} \\
{\left[\mathrm{AlCl}_{4}\right]_{2}} \\
/ \mathrm{ppm}\end{array}$ \\
\hline 19.3 & & & & & -2.3 \\
21.7 & 22.7 & 22.7 & 22.2 & 22.2 & 19.8 \\
29.5 & 32.0 & 32.5 & 32.5 & 32.5 & 32.5 \\
$344 \pm 2$ & $349 \pm 10$ & $354 \pm 10$ & $349 \pm 10$ & $354 \pm 10$ & $351 \pm 10$ \\
\hline
\end{tabular}

The ${ }^{31} \mathrm{P}$ CP/MAS NMR signals from the central phosphorus nuclei resonate further downfield: For the monocation series [2]Cl, the chlorine-bound phosphorus nuclei show sharp isotropic chemical shift peaks between 126 and $174 \mathrm{ppm}$ (Table 1). The differences between the shifts in the solid state and those observed in the solution ( 134 ppm) stem from crystal packing. The intensity differences of the two isotropic shift peaks in the spectra of compound [2a]Cl are likely due to a mixture of crystal structures, possibly caused by the chiral properties of the central phosphorus; two independent molecules in the asymmetric unit cell, as found by X-ray, should give equally intense lines. 
Unlike the spectra of the monocation precursors, the central phosphorus nuclei of the dicationic products $\mathbf{3 a - c} \mathbf{c}^{2+}$ show broad isotropic peaks shifted even further downfield around $350 \mathrm{ppm}$. The widths of these peaks in the solid state reveal a significant amount of structural disorder, such as variations in bond angles, bond distances. Interestingly, the phosphorane substitutions, amino group ligands and counterions do not impact the peak positions and widths of the center phosphorous with the exception of compound $[3 \mathbf{3 a}]\left[\mathrm{SbF}_{6}\right]_{2}$. Of the latter the comparatively sharp peak of the center phosphorus at $344 \mathrm{ppm}$ resonates at the lower shift range sampled by the other dicationic compounds. It seems that the $\left[\mathrm{SbF}_{6}\right]^{-}$counter ion in the dication series causes the material to crystallize with less disorder in a structure only present to a minor amount in the other compounds. Overall, the isotropic chemical shifts of these phosphorus centers agree with the values observed in solution (356 ppm) and the large downfield shift is consistent with electron depletion at the central phosphorus nucleus. The spread of the total intensities over a wide range of spinning sidebands reveal large chemical shift anisotropies, consistent with the highly asymmetric electron distribution around the doubly bonded phosphorus nuclei and its empty $\mathrm{p}_{z}$ orbital.

\section{Computational analysis}

In order to understand the electronic structure of the dication better, we have analyzed its structural features computationally, with a particular focus on the CPN fragment. First, B3PW91/6-31G(d) level geometries were optimized for $\mathbf{3} \mathbf{a}^{2+}$ and its model $\mathbf{3} \mathbf{e}^{2+}$, wherein hydrogen atoms replace the phosphorane phenyl and nitrogen isopropyl groups (Figure 7). Both geometries are similar, show near-planarity about the CPN moiety, and agree well with the experimental X-ray structure. The C-PN (1.745 and $1.742 \AA$ for $\mathbf{3 a}^{2+}$ and $\mathbf{3} \mathrm{e}^{2+}$, respectively) and P-N (1.647 and 1.629 $\AA$ A) distances lie between typical single and double bond lengths. As indicated previously, this suggests a $4 \pi$ heteroallyl description that formally arises from the presence of one electron pair on each terminal atom $(\mathrm{C}$ and $\mathrm{N})$ and a vacant $\mathrm{p}_{\square}$ orbital on the central phosphorus.

This description is confirmed by an NBO (natural bond order) analysis, which provides a quantitative description of the electronic structure in terms of localized electron-pair bonding units ${ }^{18}$. The NBO treatment for $\mathbf{3 a}^{2+}$ and $\mathbf{3 e}^{2+}$ indicates that the CPN moiety features a 3 center / $4 \pi$-electron bond and that the electronic structure can be described on the basis of two resonance forms: one having a $\mathrm{C}=\mathrm{P}$ double bond and a $\pi$-lone pair (LP) on the nitrogen atom, and the other having a carbon $\pi$-lone pair and a $\mathrm{P}=\mathrm{N}$ double bond. Each resonance structure gives lone pairs that have low electron occupancy (between 1.54 and 1.69 electrons) and a large LP $\rightarrow \pi^{*}$ second-order interaction energy (with $\mathrm{E}(2)$ values being between 200 and $257 \mathrm{~kJ} / \mathrm{mol}$ ), as would be expected for a 3 center / 4- $\pi$ electron description. A natural resonance theory (NRT) analysis ${ }^{19}$, confined to the CPN moiety of $3 \mathrm{e}^{2+}$, confirms the co-existence of two resonance structures having high weights (Figure 8). It should be noted that the NRT calculation gives a weight of $0 \%$ for the resonance structure in which both $\pi$-lone-pair at the $\mathrm{C}$ and $\mathrm{N}$ atoms are not delocalized over the phosphorus cationic center (i.e a C-P(+)-N structure). When the same analysis is performed for $\mathrm{H}_{2} \mathrm{C}=\mathrm{P}-\mathrm{NH}_{2}$, much less delocalization of the nitrogen lone pair into the $\pi \mathrm{P}=\mathrm{C}$ bond $(\mathrm{E}(2)=81 \mathrm{~kJ} / \mathrm{mol})$ is found, and the weights of the canonical $\mathrm{H}_{2} \mathrm{C}=\mathrm{P}-\mathrm{NH}_{2}$ resonance structure $(92.1 \%)$ and of the zwitterionic structure ${ }^{-} \mathrm{H}_{2} \mathrm{C}-\mathrm{P}=\mathrm{NH}_{2}{ }^{+}(6.7 \%)$ are very different.
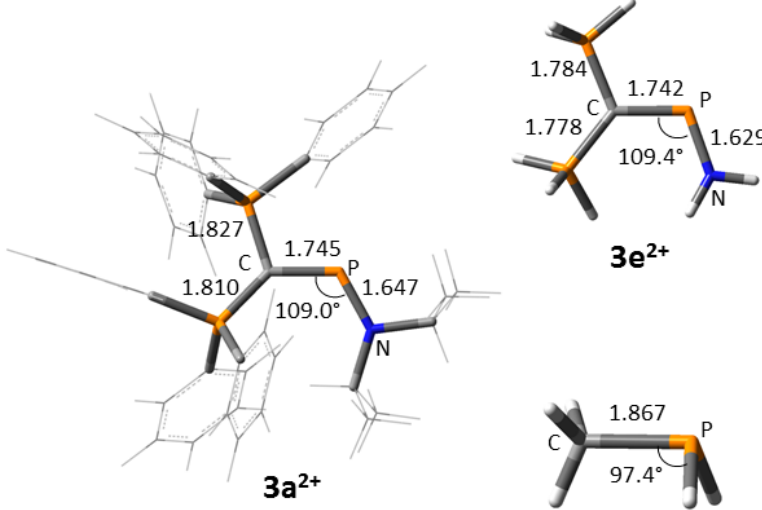

$3 e^{2+}$

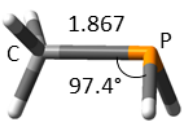

$\mathrm{H}_{3} \mathrm{C}-\mathrm{PH}_{2}$
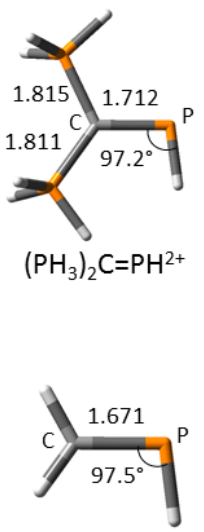

$\mathrm{H}_{2} \mathrm{C}=\mathrm{PH}$

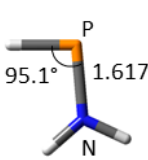

$\mathrm{H}_{2} \mathrm{~N}=\mathrm{PH}^{+}$

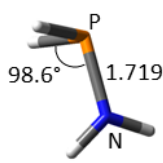

$\mathrm{H}_{2} \mathrm{~N}-\mathrm{PH}_{2}$

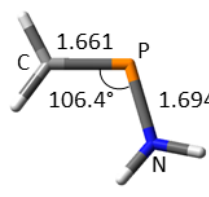

$\mathrm{H}_{2} \mathrm{C}=\mathrm{P}-\mathrm{NH}_{2}$

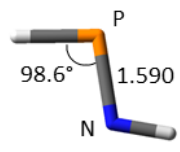

$\mathrm{HN}=\mathrm{PH}$

Figure 7. Optimized geometries of the studied molecules at the B3PW91/6-31G(d) level. A wireframe representation of the substituents of $3 \mathbf{a}^{2+}$ is used for clarity. 
The Lewis representation of these resonance structures (Figure 8) places a formal neutral charge on the CPNphosphorus center and therefore implies non-electrophilic character, which would clearly contradict both the spectroscopic data and the reactivity of $\mathbf{3} \mathbf{a}^{\mathbf{2 +}}$. This discrepancy can be explained through an examination of $\pi$-bond polarization (Table 3 ). Both the $\mathrm{CP}$ and the PN $\pi$-bonds are highly polarized, toward the carbon and nitrogen atoms respectively, and this means that the $\pi$-population on the phosphorus center $\left(0.70\right.$ and 0.61 electron for $3 \mathbf{a}^{2+}$ and $\mathbf{3 e}^{2+}$, respectively) is significantly lower than in other compounds containing $\mathrm{P}=\mathrm{X}$ double bonds such as $\mathrm{H}_{2} \mathrm{C}=\mathrm{PH}(0.92$ electron), $\mathrm{H}_{2} \mathrm{C}=\mathrm{P}-\mathrm{NH}_{2}$ (0.86 electron) or $\mathrm{HN}=\mathrm{PH}(0.73$ electron) (Table 3$)$. An even lower $\pi$-population is calculated for the phosphorus center when hydride replaces either of the $\pi$-donor groups, $\mathrm{NR}_{2}^{-}$or $\left(\mathrm{PR}_{3}\right)_{2} \mathrm{C}$, and this highlights the role of both of these groups in stabilizing $\mathbf{3 a}^{2+}$.It is noteworthy that whilst the total $\pi$-population at the CPN moiety is noticeably less than 4.00 in the case of $\mathbf{3} \mathbf{a}^{2+}$ and $\mathbf{3} \mathbf{e}^{2+}$, and less than 2.00 for $\left(\mathrm{PH}_{3}\right)_{2} \mathrm{C}=\mathrm{PH}^{2+}$, the other molecules in Table 3 give essentially perfect values. This suggests an interaction between the $\pi$-MOs of the CPN moiety and the $\mathrm{PR}_{3}$ groups. The degree of this hyperconjugation between the $\sigma * \mathrm{P}-\mathrm{R}$ and $\pi \mathrm{C}=\mathrm{P}$ orbitals (or the formal $\pi$ lone-pair on C) can be estimated through the computation of their second-order interaction energies, which are found to total 78, 92 and $66 \mathrm{~kJ} / \mathrm{mol}$ for $\mathbf{3 a}^{2+}, \mathbf{3 e}^{2+}$ and $\left(\mathrm{PH}_{3}\right)_{2} \mathrm{C}=\mathrm{PH}^{2+}$, respectively. It explains why the $\mathrm{C}-\mathrm{PR}_{3}$ bond lengths lie between single and double bond values (mean lengths being $1.818,1.781$ and $1.813 \AA$ for $\mathbf{3 a}^{2+}, \mathbf{3 e}^{2+}$ and $\left(\mathrm{PH}_{3}\right)_{2} \mathrm{C}=\mathrm{PH}^{2+}$, respectively). Furthermore, $\pi$-donation from the carbon atom to the CPN-phosphorus center diminishes when the $\mathrm{NR}_{2}$ group in $\mathbf{3} \mathbf{a}^{2+}$ and $\mathbf{3} \mathbf{e}^{2+}$ contributes to the $\pi$-system; instead, it becomes more involved in hyperconjugation with the $\left(\mathrm{PR}_{3}\right)_{2} \mathrm{C}$ moiety.

The energy barrier to rotation about the $\mathrm{CP}$ and PN bonds provides another measure of the degree of $\pi$ interaction in the bonds comprising the CPN moiety. The bulk of the substituents in $\mathbf{3} \mathbf{a}^{2+}$ is likely to cause a significant steric bias, so this analysis was only performed for $\mathbf{3} \mathbf{e}^{2+}$. A planarized analogue of $\mathbf{3} \mathbf{e}^{2+}$, which we label $\mathbf{3} \mathbf{e}_{\mathbf{p}}{ }^{2+}$ was computed, and found to lie $7.9 \mathrm{~kJ} / \mathrm{mol}$ higher in energy than $3 \mathbf{e}^{2+}$ itself. A rotation of $90^{\circ}$ around the PC bond of $3 \mathbf{e}_{\mathbf{p}}{ }^{2+}$ was then performed. Subsequent optimization without full relaxation of the geometry, so that the planarity at the $\mathrm{C}$ and $\mathrm{N}$ atoms is retained, led to $3 \mathrm{ec}^{2+}$. A similar rotation about the PN bond gave $3 \mathbf{e}^{2+}$ (Figure 9). In both cases, changes consistent with significant $\pi$ bonding were observed, with the bond undergoing the rotation lengthening and the other bond to phosphorus shortening slightly. In the case of $\mathbf{3 e c}^{2+}$, where rotation blocks any delocalization of the PCP carbon $\pi$ electron density onto the phosphorus atom, a shorter C-PR 3 bond is also observed, which reflects the hyperconjugation discussed above.

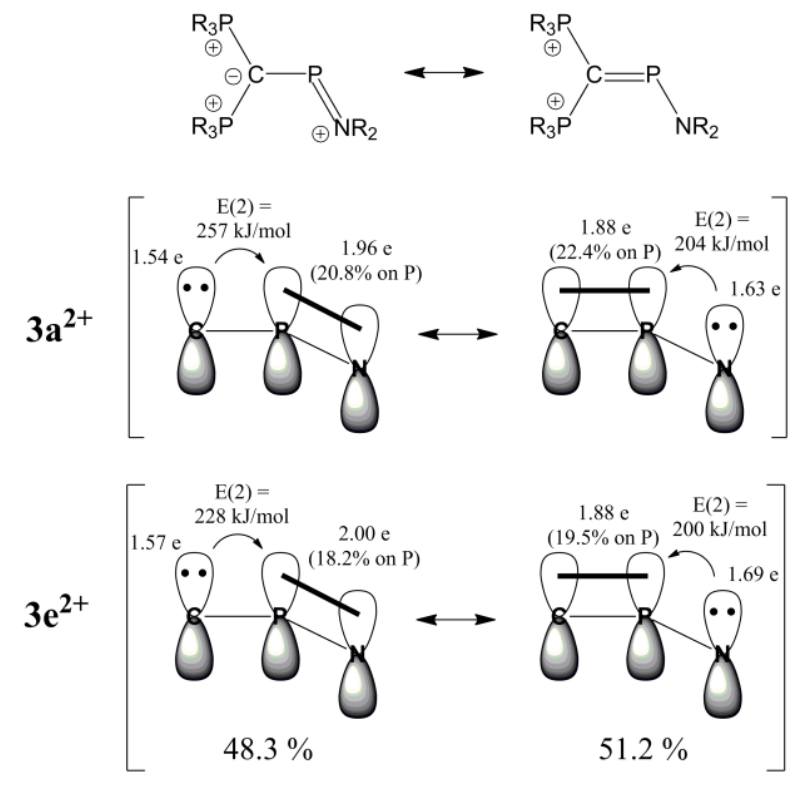

Figure 8. NBO/NRT resonance structures of $\mathbf{3 a}^{2+}$ and $\mathbf{3} \mathbf{e}^{2+}$ calculated at the B3PW91/6-311+G(d,p)//B3PW91/6-31G(d) level.

The opposite trend is observed for $\mathbf{3 e}_{\mathbf{N}}{ }^{\mathbf{2}}$, where the nitrogen lone pair no longer attenuates delocalization of the PCP carbon $\pi$-electron density. The energies of $\mathbf{3 e c}^{2+}(66.4)$ and $\mathbf{3} \mathbf{e}_{\mathbf{N}}{ }^{2+}\left(66.8 \mathrm{kJmol}^{-1}\right)$ relative to $\mathbf{3} \mathbf{e}^{2+}$ (Figure 9 ), confirm that the $\mathrm{CP}$ and $\mathrm{PN} \pi$ bonds have similar strength, i.e. that both $\mathrm{C}=\mathrm{P}-\mathrm{N}$ and $\mathrm{C}-\mathrm{P}=\mathrm{N}$ resonance forms have similar weight. This analysis is therefore in good agreement with the NBO results.

One last question, concerning the nature of the $\mathrm{CP} \sigma$ bond in $\mathbf{3} \mathbf{a}^{2+}$ and $\mathbf{3} \mathbf{e}^{2+}$, has also been addressed. Several structural formulae, with or without donor-acceptor interactions, can be used to describe these molecules (Figure 10). 
Assembling several closed-shell chemical groups through the use of dative bonds is a modern way to represent molecules, and $\mathbf{3} \mathbf{a}^{2+}$ and $\mathbf{3} \mathbf{e}^{2+}$ can be depicted in this fashion as an assembly of a carbodiphosphorane(itself built from one carbon atom in its ${ }^{1} \mathrm{D}$ excited state and two phosphane ligands) and a dicationic $\mathrm{P}-\mathrm{NR}_{2}$ group that formally has a lone pair and two vacant orbitals at the phosphorus center. Equally, a more conventional description including only covalent bonds is possible. It should be emphasized that both of the structures given in Fig. 10 constitute highly limiting descriptions of the real electronic structure.
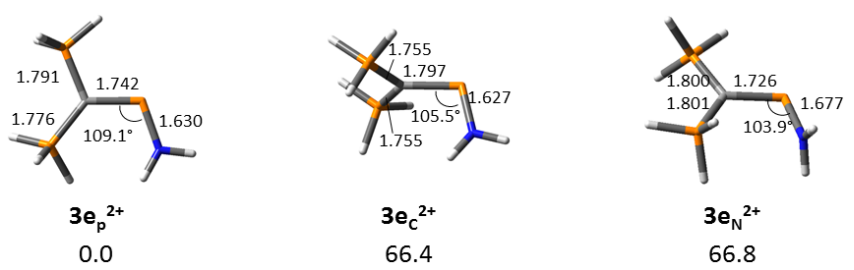

Figure 9. Optimized geometries and relative energies $\left(\mathrm{kJmol}^{-1}\right)$ computed at the B3PW91/6-311+G(d,p)//B3PW91/6-31G(d) level.

\begin{tabular}{|c|c|c|c|c|c|}
\hline & $\% \mathrm{P}^{[\mathrm{a}]}$ & $\mathrm{C}$ & $\mathrm{P}$ & $\mathrm{N}$ & $\Sigma$ pop $^{[\mathrm{b}]}$ \\
\hline $\mathrm{H}_{2} \mathrm{C}=\mathrm{PH}$ & 46.4 & 1.07 & 0.92 & - & 1.99 \\
\hline $\begin{array}{l}\mathrm{H}_{2} \mathrm{C}=\mathrm{P}- \\
\mathrm{NH}_{2}\end{array}$ & 39.0 & 1.26 & 0.86 & 1.84 & 3.96 \\
\hline $\mathrm{HN}=\mathrm{PH}$ & 36.8 & - & 0.73 & 1.26 & 1.99 \\
\hline $3 \mathbf{a}^{2+}$ & $22.4 / 20.8$ & 1.53 & 0.70 & 1.63 & 3.86 \\
\hline $3 \mathrm{e}^{2+}$ & $19.5 / 18.3$ & 1.57 & 0.61 & 1.68 & 3.86 \\
\hline $\begin{array}{l}\left(\mathrm{PH}_{3}\right)_{2} \mathrm{C}=\mathrm{P} \\
\mathrm{H}^{2+}\end{array}$ & 27.2 & 1.40 & 0.53 & - & 1.93 \\
\hline $\mathrm{H}_{2} \mathrm{~N}=\mathrm{PH}^{+}$ & 22.4 & - & 0.44 & 1.55 & 1.99 \\
\hline
\end{tabular}

[a] Percentage contribution of the $P$ atom to the $\pi C=P / N=P$ bond. [b] Sum of the $\pi$-population at the $\mathrm{C}, \mathrm{P}$ and $\mathrm{N}$ atoms.

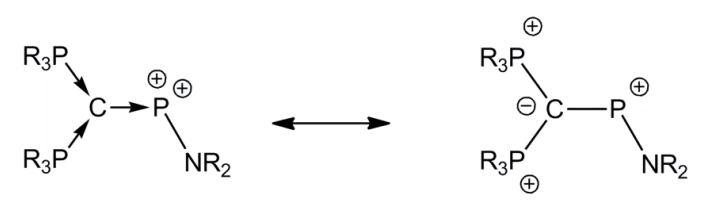

Figure 10. "Extreme" model representations of $3 \mathbf{a}^{2+}$ and $\mathbf{3} \mathbf{e}^{2+}$.

Examination of the $\sigma$-bond polarization through NBO analysis provides a precise description of the bonds. Data in Table 4 indicate that the C-PNR 2 bonds in $\mathbf{3 a}^{\mathbf{2 +}}, \mathbf{3} \mathbf{e}^{\mathbf{2 +}}$ and $\left(\mathrm{PH}_{3}\right)_{2} \mathrm{C}=\mathrm{PH}^{2+}$ are highly polarized, with greater than usual electron density on the carbon atom. In as much as this implies a situation where the carbon retains more electron density than in the more classical $\sigma \mathrm{PC}$ bonds found in $\mathrm{H}_{3} \mathrm{C}-\mathrm{PH}_{2}, \mathrm{H}_{2} \mathrm{C}=\mathrm{PH}$ or $\mathrm{H}_{2} \mathrm{C}=\mathrm{P}-\mathrm{NH}$, the carbone- $\mathrm{P}$ bond can be considered to have a degree of dative character. On the contrary, the $\sigma \mathrm{R}_{3} \mathrm{P}-\mathrm{C}$ bonds of the carbone components in $\mathbf{3 a}^{2+}, \mathbf{3 e}^{\mathbf{2 +}}$ and $\left(\mathrm{PH}_{3}\right)_{2} \mathrm{C}=\mathrm{PH}^{2+}$ show polarization that is similar to a classical $\sigma \mathrm{P}-\mathrm{C}$ bond, which implies that an $\mathrm{R}_{3} \mathrm{P} \rightarrow \mathrm{C}$ description is not consistent with their electronic structure. The $\mathrm{P}-\mathrm{N} \sigma$ bonds present an even stronger polarization toward $\mathrm{N}$, but such bonds are never described using dative formulations. The high polarization of both the $\sigma$ and $\pi$ components within the $\mathrm{PC}$ and $\mathrm{PN}$ bonds that comprise the CPN moiety of $\mathbf{3 a}^{\mathbf{2 +}}$ and $\mathbf{3} \mathrm{e}^{2+}$ results in little charge transfer from $\left(\mathrm{PR}_{3}\right)_{2} \mathrm{C}$ to the 
formally dicationic phosphorus center in the "dative" resonance hybrid. Consequently, the NPA atomic charge remains significantly positive on $\mathrm{P}\left(+1.19\right.$ and +1.27 e for $3 \mathbf{a}^{2+}$ and $\mathbf{3} \mathbf{e}^{2+}$, respectively) (Table 5$)$. The $\left(\mathrm{PR}_{3}\right)_{2} \mathrm{C}$ moiety shows a zwitterionic structure having positive charge on the phosphane groups $\left(+1.18\right.$ and $+1.14 \mathrm{e}$ for $\mathbf{3} \mathbf{a}^{2+}$ and $\mathbf{3} \mathrm{e}^{2+}$, respectively) and a negative charge at the central carbon atom (-1.42 and $-1.40 \mathrm{e})$. Finally, the $\mathrm{NR}_{2}$ group is almost neutral ( -0.14 and -0.16 e) due to an opposing 'pull' of $\sigma$ and "push" of $\pi$ electron density.

Table 4. NBO polarization of the PC and PN $\sigma$ bond calculated at the B3PW91/6-311+G(d,p)//B3PW91/6-31G(d) level.

\begin{tabular}{|c|c|c|c|c|}
\hline & $\begin{array}{l}\text { Bond } \\
\text { Length } \\
(\AA)\end{array}$ & $\begin{array}{l}\% \\
\mathrm{P}^{[\mathrm{a}]}\end{array}$ & & $\begin{array}{l}\text { Bond } \\
\text { Length } \\
(\AA)\end{array}$ \\
\hline PC bonds & & & PN bonds & \\
\hline $\mathrm{H}_{3} \mathbf{C}-\mathrm{PH}_{2}$ & 1.867 & 39.2 & $\mathrm{H}_{2} \mathbf{N}-\mathbf{P H}_{2}$ & 1.719 \\
\hline $\mathrm{H}_{2} \mathbf{C}=\mathbf{P H}$ & 1.671 & 37.5 & $\mathrm{HN}=\mathbf{P H}$ & 1.590 \\
\hline $\mathrm{H}_{2} \mathbf{C}=\mathbf{P}-\mathrm{NH}_{2}$ & 1.661 & 38.2 & $\mathrm{H}_{2} \mathrm{C}=\mathbf{P}-\mathbf{N H}_{2}$ & 1.687 \\
\hline $\begin{array}{l}\left(\mathrm{Ph}_{3} \mathrm{P}\right)_{2} \mathbf{C}-\mathbf{P}- \\
\mathrm{N}^{i} \mathrm{Pr}_{2}{ }^{2+}\left(\mathbf{3 a}^{2+}\right)\end{array}$ & 1.743 & 31.8 & $\begin{array}{l}\left(\mathrm{Ph}_{3} \mathrm{P}\right)_{2} \mathrm{C}-\mathbf{P}- \\
\mathbf{N}^{\mathrm{i}} \mathrm{Pr}_{2}{ }^{2+}\left(\mathbf{3 a}^{\mathbf{2 +}}\right)\end{array}$ & 1.647 \\
\hline $\begin{array}{l}\left(\mathrm{H}_{3} \mathrm{P}\right)_{2} \mathbf{C}-\mathbf{P}- \\
\mathrm{NH}_{2}{ }^{2+}\left(\mathbf{3 e}^{2+}\right)\end{array}$ & 1.742 & 30.9 & $\begin{array}{l}\left(\mathrm{H}_{3} \mathrm{P}\right)_{2} \mathbf{C}-\mathbf{P}- \\
\mathbf{N H}_{2}{ }^{2+}\left(\mathbf{3 e}^{2+}\right)\end{array}$ & 1.629 \\
\hline $\begin{array}{l}\left(\mathrm{H}_{3} \mathrm{P}\right)_{2} \mathbf{C}- \\
\mathbf{P H}^{2+}\end{array}$ & 1.712 & 30.1 & $\mathrm{H}_{2} \mathbf{N}=\mathbf{P H}^{+}$ & 1.617 \\
\hline $\begin{array}{l}\left(\mathrm{Ph}_{3} \mathbf{P}\right)_{2} \mathbf{C}-\mathrm{P}- \\
\mathrm{N}^{i} \mathrm{Pr}_{2}\left(\mathbf{3 a}^{\mathbf{2 +}}\right)\end{array}$ & 1.821 & 37.6 & & \\
\hline $\begin{array}{l}\left(\mathrm{H}_{3} \mathbf{P}\right)_{2} \mathbf{C}-\mathrm{P}- \\
\mathrm{NH}_{2}\left(\mathbf{3 e}^{2+}\right)\end{array}$ & 1.781 & 38.8 & & \\
\hline$\left(\mathrm{H}_{3} \mathbf{P}\right)_{2} \mathbf{C}-\mathrm{PH}$ & 1.813 & 38.9 & & \\
\hline
\end{tabular}

[a] Percentage contribution of the P atom to the $\sigma$ CP/NP bond.

Table 5. NPA atomic/group electronic charge (in electron) of $3 \mathrm{a} 2+$ and $3 \mathrm{e} 2+$ calculated at the B3PW91/6311+G(d,p)//B3PW91/6-31G(d) level.

\begin{tabular}{lll}
\hline & $\mathbf{3 a}^{\mathbf{2}}$ & $\mathbf{3 e}^{\mathbf{2 +}}$ \\
\hline $\mathrm{P}^{[\mathrm{a}]}$ & +1.19 & +1.27 \\
$\mathrm{NR}_{2}$ & -0.14 & -0.16 \\
$\mathrm{C}$ & -1.42 & -1.40 \\
$\mathrm{PR}_{3}$ & +1.18 & +1.14 \\
\hline
\end{tabular}

[a] phosphorus atom of the CPN moiety.

\section{$\underline{\text { Reactivity }}$}

Our initial investigation involved the reaction of $[\mathbf{3 a}]\left[\mathrm{AlCl}_{4}\right]_{2}$ or $[\mathbf{3 a}]\left[\mathrm{BAr}_{4}^{\mathrm{f}}\right]_{2}$ with $4-\mathrm{Me}_{2} \mathrm{~N}-\mathrm{C}_{5} \mathrm{H}_{4} \mathrm{~N}$ (DMAP). ${ }^{[6 \mathrm{~d}]}$ While multinuclear NMR suggested coordination of the pyridine to the central $\mathrm{P}$ in the presence of $\mathrm{BAr}_{4}^{\mathrm{f}_{4}^{-}}$, anion interference and subsequent formation of the monocationic precursor $\mathbf{2 a}^{+}$and $\mathrm{DMAP} \cdot \mathrm{AlCl}_{3}$ were observed with $[3 \mathbf{a}]\left[\mathrm{AlCl}_{4}\right]_{2}$. This counterion interference can be explained within the same hard-soft acid-base framework that has been used to rationalize related compounds having $\mathrm{AlCl}_{4}{ }^{-}$anions. ${ }^{[1 \mathrm{~d}]}$ Similar anion interference was also observed when $\mathrm{PMe}_{3}$ was reacted with DCM solutions of $[3 \mathbf{3 a}]\left[\mathrm{AlCl}_{4}\right]_{2}$. According to variable temperature (VT) ${ }^{31} \mathrm{P}$ NMR, two dynamic equilibria were detected for this system: it was possible to observe the formation of not only the target adduct $\left[3 \mathbf{3 a} \cdot \mathbf{P M e}_{3}\right]\left[\mathrm{AlCl}_{4}\right]_{2}$ but also the monocationic precursor $\left(\mathbf{2 a}^{+}\right)$and the $\mathrm{Me}_{3} \mathrm{P} \cdot \mathrm{AlCl}_{3}$ adduct (Scheme 3). Such anion interference was eliminated when $\mathrm{BAr}_{4}^{\mathrm{f}}{ }^{-}$was used as the counterion, so that the equilibrium between the free dication 
and the corresponding phosphine adduct could then be studied cleanly (Scheme 3). It was possible to obtain a van't Hoff plot, by VT ${ }^{31} \mathrm{P}$ NMR spectroscopy, from which the thermodynamic parameters $\Delta \mathrm{H}=-30.5 \mathrm{kJmol}^{-1}$ and $\Delta \mathrm{S}=-$ 77.7 eu have been extracted. The enthalpy of the adduct i.e. the P-P bond formation was significantly less than the value established for a single P-P bond $\left(\sim 200 \mathrm{kJmol}^{-1}\right)^{20}$ suggesting a very weak P-P bond which is consistent with the equilibrium nature of this system. Additionally, similar thermodynamic parameters $\left(\Delta \mathrm{H}=-37.5 \mathrm{kJmol}^{-1}\right.$ and $\Delta \mathrm{S}=-$ $110.5 \mathrm{eu}$ ) were obtained when $\mathrm{PMe}_{3}$ was added to the DCM solution containing $[3 \mathbf{c}]\left[\mathrm{BAr}_{4}^{\mathrm{f}}\right]_{2}$.

Scheme 3. Observed equilibria.

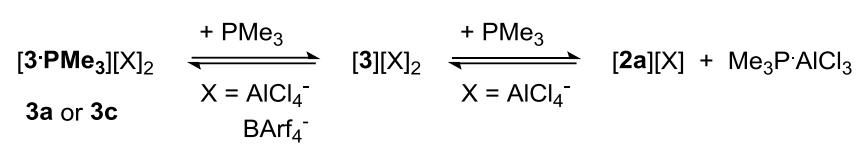

Furthermore, as previously reported, the addition of 1 equiv of water or methanol (or their deuterated analogues) to the solution containing $[3 \mathbf{a}]\left[\mathrm{BAr}_{4}^{\mathrm{f}}\right]_{2}$ resulted in an immediate color change that was highlighted by $\mathrm{H}-\mathrm{O}$ bond activation and formation of compounds $\mathbf{4}^{2+}$ and $\mathbf{5}^{\mathbf{2 +}}$ respectively (Scheme 4). ${ }^{5 \mathrm{~d}}$ The identity of these two products were established by multinuclear NMR clearly indicating the presence of P-H and P-OR $(\mathrm{R}=\mathrm{H}, \mathrm{Me})$ fragments. Furthermore, the same set of data suggested that the $\mathrm{O}-\mathrm{H}$ proton for $\mathbf{4}^{2+}$ was fluxional between the $\mathrm{O}$ and $\mathrm{N}$ atoms to form $\mathbf{6}^{2+}$ (Scheme 4). This fluxional proton was then easily abstracted by $\mathrm{NEt}_{3}$ to form the crystallographically characterized $\mathbf{7}^{2+}$ whose structure confirms $\mathrm{O}-\mathrm{H}$ bond cleavage for the used substrates. (Figure 11). Considering that no activators (e.g. boranes) were added and the reactions could also proceed at low temperatures, this type O-H bond activation at a single site was rarely reported in the literature. ${ }^{21,22}$ In fact, only two metal-based compounds ( $\mathrm{Ru}$ and $\mathrm{Ga}(\mathrm{I})$ ) were shown to similarly activate water under the same reaction conditions. ${ }^{22}$ Furthermore, the use of $\mathrm{SbF}_{6}$, instead of $\mathrm{BAr}_{4}{ }^{-}$, did not interfere with these oxidative additions; this is a significant observation because purification by recrystallization of the dication in the presence of $\mathrm{SbF}_{6}^{-}$appeared to be much simpler than with the bulky borate anions $\left(\mathrm{BAr}_{4}^{-}, \mathrm{Bar}_{4}^{\mathrm{Cl}}{ }_{4}^{-}\right)$. Lastly, leaving $\sim 10$ $\mathrm{mg}$ of $\mathbf{3 a}^{2+}$ in about1 $\mathrm{ml}$ of THF solution overnight resulted in solvent polymerization which has been reported for a borenium cation. ${ }^{23}$ Interestingly, the $\delta_{\mathrm{P}}$ signal for the central $\mathrm{P}$ of the dication in THF did not deviate from its usual value of $356 \mathrm{ppm}$ suggesting that the dication-THF interaction is minimal but sufficient to cause the polymerization. In view of these initial reactivity studies involving $3 \mathbf{a}^{2+}$ and oxygen-containing substrates it might be postulated that these dications, in general, are quite oxophilic. We are currently exploring the chemistry of $\mathbf{3 a}^{2+}$ towards several oxygencontaining substrates and the results from these studies will be reported in due course.

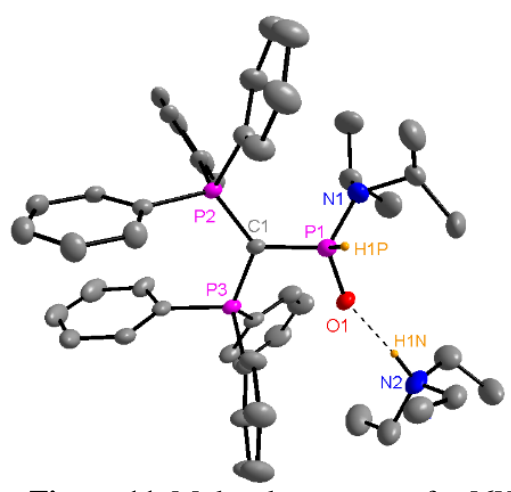

Figure 11. Molecular structure for $[6]\left[\mathrm{BAr}_{4}^{\mathrm{f}}\right]_{2}$. Thermal ellipsoids are shown at the $50 \%$ probability level. The anions and all hydrogen atoms, except the ones found at $\mathrm{P} 1$ and N2, have been omitted for clarity. Selected bond lengths $(\AA)$ and angles $\left(^{\circ}\right)$ P1-C1 1.762(4), P1-O1 1.498(3), P1-N1 1.640(4), O1-N2 2.717(5), P2-C1 1.748(4), P3-C1 1.757(4), O1-P1-N1 118.19(19), O1-P1-C1 106.06(17), C1-P1-N1 114.03(19). 
Scheme 4. Reactivity of dication $3 \mathbf{a}^{2+}$ with water and methanol.

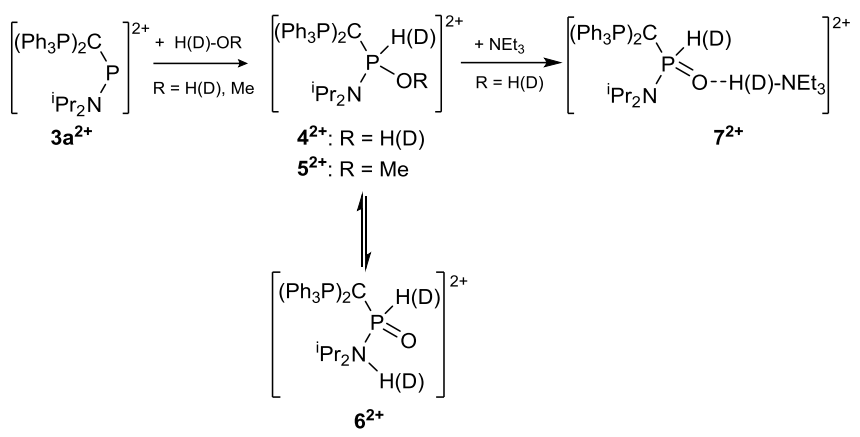

\section{CONCLUSIONS}

The reported synthesis of dication $\mathbf{3} \mathbf{a}^{2+}$ has been extended to two more examples $\left(\mathbf{3} \mathbf{b}^{2+}\right.$ and $\left.\mathbf{3} \mathbf{c}^{\mathbf{2 +}}\right)$ that bear different amine and carbone substituents. The reaction between a cyclic carbone $\left(\left(\mathrm{Ph}_{2} \mathrm{P}\left(\mathrm{CH}_{2}\right)_{3} \mathrm{PPh}_{2}\right) \mathrm{C}, \mathbf{1 b}\right)$ and $\mathrm{Cy}_{2} \mathrm{NPCl}_{2}$ did not result in the formation of the target monocationic precursor, thus preventing the synthesis of the corresponding dication. The combined steric demands of these two substrates are assumed to be the cause of the failed reaction. The $\delta_{\mathrm{P}}$ signals corresponding to the central $\mathrm{P}$ for the new dications $\left(\mathbf{3 a}^{\mathbf{2 +}}-\mathbf{3} \mathbf{c}^{\mathbf{2 +}}\right)$ were observed around $360 \mathrm{ppm}$, which is in a good agreement with other related phosphenium cations. The solid state ${ }^{31} \mathrm{P}$ CP MAS NMR produced virtually identical shifts for these $\mathrm{P}$ signals, with a minor counterion dependence being observed only for $\mathbf{3} \mathbf{c}^{\mathbf{2}}$. This was somewhat surprising, given that single crystal $\mathrm{X}$-ray analysis for $[\mathbf{3 a}][\mathrm{X}]_{2}\left(\mathrm{X}=\mathrm{AlCl}_{4}, \mathrm{SbF}_{6}\right.$ and $\left.\mathrm{BAr}_{4}^{\mathrm{f}}\right)$ showed different degrees of interion interaction. The $\mathrm{SbF}_{6}{ }^{-}$anions gave the greatest interion contact, and this is thought to be responsible for the quenching of the usual yellow color of the dications in the solid state. Solution state ${ }^{31} \mathrm{P}$ NMR analyses indicate an essential absence of any interion contacts because the $\delta_{\mathrm{P}}$ signals do not vary with the changing nature of the counterions. It is noteworthy that whilst $3 \mathbf{a}^{2+}$ was stable in the presence of coordinating $\left(\mathrm{AlCl}_{4}^{-}\right)$and weakly coordinating anions $\left(\mathrm{BAr}_{4}^{\mathrm{f}}\right)$, it was not possible to isolate this dication in the presence of oxygen-containing anions $\left(\mathrm{OTf}^{-}, \mathrm{ClO}_{4}{ }^{-}\right)$or anionic p- block complex fluorides $\left(\mathrm{BF}_{4}^{-}, \mathrm{PF}_{6}^{-}\right)$. The Lewis acids $\mathrm{BF}_{3}$ and $\mathrm{PF}_{5}$ are therefore assumed to be less fluorophilic than $\mathbf{3 a}^{2+}$.

Comparative X-ray analyses of several monocationic precursors and dicationic species suggested a $4 \pi$ allyl-like

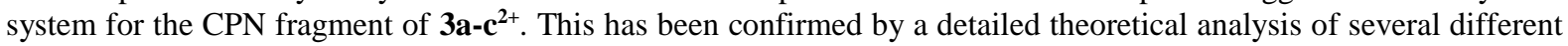
model compounds. The degree to which the carbone and amino substituents donate $\pi$ electron density into the formally vacant $\mathrm{p}_{\mathrm{z}}$ orbital on the central $\mathrm{P}$ is found to be very similar.

Reactivity patterns for $3 \mathbf{a}^{2+}$ and/or $\mathbf{3} \mathbf{c}^{2+}$ have been explored in the presence of DMAP, $\mathrm{PMe}_{3}, \mathrm{HOR}(\mathrm{R}=\mathrm{H}, \mathrm{Me})$ and THF as a solvent. A dynamic equilibrium was observed after the addition of $\mathrm{PMe}_{3}$ to DCM solution of $\left.[\mathbf{3 a} / \mathbf{3 c}]_{[\mathrm{BAr}}{ }_{4}\right]_{2}$. Thermodynamic parameters were extracted from van ' $t$ Hoff plots that were obtained from variable temperature ${ }^{31} \mathrm{P}$ NMR studies. Additionally, dication $\mathbf{3} \mathbf{a}^{\mathbf{2 +}}$ was a quite potent reagent for stoichiometric $\mathrm{O}-\mathrm{H}$ bond cleavage when it was treated with 1 equiv of water or methanol in DCM solution. Lastly, solvent polymerization was observed when $\mathbf{3 a}^{2+}$ was dissolved in THF.

\section{ASSOCIATED CONTENT}

\section{Supporting Information}

Copies of crystal information files, coordinates of the computed structures and multinuclear NMR spectra of the newly synthesized dications. The Supporting Information is available free of charge on the ACS Publications website.

\section{AUTHOR INFORMATION}

\section{Corresponding Author}

*Email: dvidovic@ntu.edu.sg; ulli.zwanziger@dal.ca; duncan.carmichael@polytechnique.edu; gilles.frison@polytechnique.edu.

Notes

The authors declare no competing financial interest. 


\section{EXPERIMENTAL SECTION}

General methods: All reactions manipulations were performed in oven-then-flame dried Schlenks or oven-dried J. Young NMR tubes, under an inert atmosphere of dry argon. Standard Schlenk line or glove box techniques were utilized. Toluene, benzene and hexane were distilled over sodium, dichloromethane (DCM) was distilled over $\mathrm{CaH}_{2}$ while THF was distilled over sodium/benzophenone. All solvents were degassed and stored over molecular sieves prior to use. The NMR spectra were obtained on a Bruker Advance III 400 (BBFO 400) spectrometer $\left({ }^{1} \mathrm{H}\right.$ NMR at $400 \mathrm{MHz} ;{ }^{13} \mathrm{C}$ at $100 \mathrm{MHz} ;{ }^{31} \mathrm{P}$ NMR at $161 \mathrm{MHz} ;{ }^{19} \mathrm{~F}$ NMR at 376 $\mathrm{MHz} ;{ }^{11} \mathrm{~B}$ at $128 \mathrm{MHz}, 27 \mathrm{Al}$ at $\left.104 \mathrm{MHz}\right) \cdot{ }^{31} \mathrm{P},{ }^{19} \mathrm{~F},{ }^{11} \mathrm{~B}$ and $27 \mathrm{Al}$ chemical shifts were referenced to $85 \% \mathrm{H}_{3} \mathrm{PO}_{4}, \mathrm{CFCl}_{3}, \mathrm{Et}_{2} \mathrm{O} \cdot \mathrm{BF}_{3}$, $\mathrm{AlCl}_{3} / \mathrm{D}_{2} \mathrm{O}$ respectively; ${ }^{1} \mathrm{H}$ and ${ }^{13} \mathrm{C}$ were referenced to tetramethylsilane (TMS). 1a $,{ }^{7 \mathrm{a}} \mathbf{1 b},{ }^{7 \mathrm{c}}[\mathbf{2 a}] \mathrm{Cl},{ }^{6 \mathrm{c}}[\mathbf{3 a}][\mathrm{X}]_{2}\left(\mathrm{X}=\mathrm{AlCl}_{4}, \mathrm{BAr}^{\mathrm{f}} 4\right),{ }^{6 \mathrm{c}}$ $\mathrm{Na}\left[\mathrm{BAr}_{4}^{\mathrm{Cl}}\right]^{24}$ have been prepared according to the reported procedures. All other chemicals have been purchased and used without further purification. Lastly, all manipulations with silver salts were performed in absence of light.

Preparation of the monocationic precursors $[\mathbf{2 b}] \mathrm{Cl}$ and $[\mathbf{2 c}] \mathrm{Cl}$ : 1 equiv of a carbone $(\mathbf{1 a}$ or $\mathbf{1 b})$ was added to a benzene solution containing 3 equiv of the corresponding $\mathrm{RPCl}_{2}(\mathrm{R}=\mathrm{iPr}$ or $\mathrm{Cy})$. Immediate formation of precipitate was observed. The solution was filtered and the resulting solid washed with hexane. The resulting solid was dried under reduced pressure.

[ $\left.{ }^{\mathrm{P}} \mathrm{H}_{2} \mathrm{NPClC}\left(\mathrm{Ph}_{2} \mathrm{P}\left(\mathrm{CH}_{2}\right)_{3} \mathrm{PPh}_{2}\right)\right][\mathrm{Cl}],[\mathbf{2 b}][\mathrm{Cl}]: 1.0 \mathrm{~g}(2.36 \mathrm{mmol})$ of $\mathbf{1 b}$ and $1.43 \mathrm{~g}(7.08 \mathrm{mmol})$ of ${ }^{\mathrm{i}} \mathrm{Pr}_{2} \mathrm{NPCl}_{2}$. Yield $0.81 \mathrm{~g}(55 \%)$.

${ }^{1} \mathrm{H}$ NMR (400 MHz, $\left.\mathrm{CD}_{2} \mathrm{Cl}_{2}, 20^{\circ} \mathrm{C}\right): 0.56\left(\mathrm{br}, 12 \mathrm{H}, \mathrm{CH}_{3}\right), 2.07\left(\mathrm{~m}, 2 \mathrm{H}, \mathrm{CH}_{2}\right), 3.30\left(\mathrm{br}, 4 \mathrm{H}_{1} \mathrm{CH}_{2}\right), 3.73(\mathrm{br}, 2 \mathrm{H}, \mathrm{CH}), 7.2-7.8(20 \mathrm{H}$, $\mathrm{Ph}) \mathrm{ppm}$.

${ }^{13} \mathrm{C}\left\{{ }^{1} \mathrm{H}\right\}$ NMR (400 MHz, $\left.\mathrm{CD}_{2} \mathrm{Cl}_{2}, 20^{\circ} \mathrm{C}\right): \delta_{\mathrm{C}} 14.8$ (m, PCP, cyclic carbone), 15.3 (s, $\mathrm{CH}_{2}\left(\mathrm{CH}_{2}\right)_{2}$, cyclic carbone) $22.3\left(\mathrm{br}, \mathrm{CH}\left(\mathrm{CH}_{3}\right) 2\right)$, 26.2 (second order triplet, $\mathrm{CH}_{2}\left(\mathrm{CH}_{2}\right)_{2}$, cyclic carbone), 48.2 (br, $\left.\mathrm{CH}\left(\mathrm{CH}_{3}\right)_{2}\right) ; 128.3-134.3\left(\mathrm{~m}, \mathrm{C}_{1}-\mathrm{C}_{4}\right.$, $\mathrm{Ph}$ of cyclic carbone) ppm.

${ }^{31} \mathrm{P}\left\{{ }^{1} \mathrm{H}\right\}$ NMR $\left(161 \mathrm{MHz}, \mathrm{CD}_{2} \mathrm{Cl}_{2}, 20^{\circ} \mathrm{C}\right): \delta \mathrm{P} 16.3$ (second order doublet, $\left.\mathrm{P}_{\text {carbone) }}\right) 138.0$ (second order triplet, $\left.\mathrm{P}_{\text {central }}\right) \mathrm{ppm}$. MS (ES+): $m / z 590(\mathrm{M}+)$ HRMS (ES+): calcd. for $\mathrm{C} 34 \mathrm{H} 40 \mathrm{NP}_{3} \mathrm{Cl}, \mathrm{m} / z$ 590.2062; found 590.2054

$\left[\mathrm{Cy}_{2} \mathrm{NPCl}\left(\mathrm{C}\left(\mathrm{PPh}_{3}\right)_{2}\right)\right][\mathrm{Cl}],[2 \mathrm{c}][\mathrm{Cl}]: 1.00 \mathrm{~g}(1.86 \mathrm{mmol})$ of $\mathbf{1 a}$ and $1.58 \mathrm{~g}(5.58 \mathrm{mmol})$ of $\mathrm{Cy}_{2} \mathrm{NPCl}_{2}$. Yield $1.23 \mathrm{~g}(81 \%)$.

${ }^{1} \mathrm{H}$ NMR (400 MHz, $\left.\mathrm{CD}_{2} \mathrm{Cl}_{2}, 20^{\circ} \mathrm{C}\right): \delta_{\mathrm{H}} 0.7-1.4\left(20 \mathrm{H}, \mathrm{CH}_{2}-\mathrm{Cy}\right), 2.84$ (br, $\left.2 \mathrm{H}, \mathrm{CH}-\mathrm{Cy}\right), 7.2-7.5$ (br, $30 \mathrm{H}, \mathrm{Ph}$ ).

${ }^{13} \mathrm{C}\left\{{ }^{1} \mathrm{H}\right\}$ NMR $\left(400 \mathrm{MHz}, \mathrm{CD}_{2} \mathrm{Cl}_{2}, 20^{\circ} \mathrm{C}\right): \delta_{\mathrm{C}} 19.9\left(\mathrm{dt},{ }^{1} J_{\mathrm{P}(\text { carbone) }}=78 \mathrm{~Hz},{ }^{1} J_{\mathrm{P}(\text { carbone) }}=104 \mathrm{~Hz}, C\left(\mathrm{PPh}_{3}\right)_{2}\right) ; 25.1\left(\mathrm{~s}, \delta-\mathrm{CH}_{2}-\mathrm{Cy}\right), 25.8$ (s, $\gamma-\mathrm{CH}_{2}-\mathrm{Cy}$ ), 33.0 (br, $\beta-\mathrm{CH}_{2}-\mathrm{Cy}$ ), 59.1 (br, $\mathrm{CH}-\mathrm{Cy}$ ), 125.7(apparent triplet $\mathrm{AA}{ }^{\prime} \mathrm{X},{ }^{1} J_{\mathrm{PC}}+{ }^{3} J_{\mathrm{PC}}=92 \mathrm{~Hz}$, ipso-C, $\mathrm{Ph}$ of $\left.\mathrm{C}\left(\mathrm{PPh}_{3}\right)_{2}\right)$; 129.3 (virtual triplet, $o-C, \mathrm{Ph}$ of $\left.\mathrm{C}\left(\mathrm{PPh}_{3}\right)_{2}\right), 134.6$ (br, $m-\mathrm{C}, \mathrm{Ph}$ of $\left.\mathrm{C}\left(\mathrm{PPh}_{3}\right)_{2}\right) \mathrm{ppm}$.

${ }^{31} \mathrm{P}\left\{{ }^{1} \mathrm{H}\right\}$ NMR $\left(161 \mathrm{MHz}, \mathrm{CD}_{2} \mathrm{Cl}_{2}, 20^{\circ} \mathrm{C}\right): \delta \mathrm{P} 26.1$ (second order doublet, $\mathrm{P}_{\text {carbone) }}, 140.5$ (second order triplet, $\left.\mathrm{P}_{\text {central }}\right) \mathrm{ppm}$. MS (ES+): $m / z, 720(\mathrm{M}+)$ HRMS (ES+): calcd. for C49H52NPCl, $\mathrm{m} / z, 720.3526$; found 720.3536 .

The synthesis of the dications $[3 \mathbf{b}][\mathrm{X}]_{2}$ and $[\mathbf{3 c}][\mathrm{X}]_{2}\left(\mathrm{X}=\mathrm{AlCl}_{4}, \mathrm{BAr}_{4}\right)$ : To a DCM $(30 \mathrm{ml})$ solution containing a monocationic precursor $([2 \mathbf{b}] \mathrm{Cl}$ or $[\mathbf{2 c}] \mathrm{Cl}) 2.1$ equiv of either $\mathrm{AlCl}_{3}$ or $\mathrm{Na}\left[\mathrm{BAr}_{4}{ }_{4}\right]$ was added. The reaction mixture was left to stir for $6 \mathrm{~h}$ followed by filtration (when $\mathrm{Na}\left[\mathrm{BAr}_{4}^{\mathrm{f}}\right]$ was used) and solvent removal under reduced pressure yielding yellow solid. It is worth noting that regardless of the nature of the counterion the multinuclear NMR data for the dicationic moieties $\left(\mathbf{3 b}^{2+}\right.$ and $\left.\mathbf{3} \mathbf{c}^{2+}\right)$ was essentially identical so the data for ion pairs is reported separately.

[ $\left.{ }^{\mathrm{P} r}{ }_{2} \mathrm{NPC}\left(\mathrm{Ph}_{2} \mathrm{P}\left(\mathrm{CH}_{2}\right)_{3} \mathrm{PPh}_{2}\right)\right]^{2+}, \mathbf{3} \mathbf{b}^{2+}: 1.0 \mathrm{~g}(1.60 \mathrm{mmol})$ of $[\mathbf{2 b}][\mathrm{Cl}]$ and 2.1 equiv of $\mathrm{AlCl}_{3}$ or $\mathrm{Na}\left[\mathrm{BAr}_{4}^{\mathrm{f}}\right]$. Yield $0.84 \mathrm{~g}(59 \%)$ as $\mathrm{AlCl}_{4}^{-}$ salt and $2.19 \mathrm{~g}(60 \%)$ as $\left[\mathrm{BAr}_{4}^{\mathrm{f}}\right]^{-}$salt.

${ }^{1} \mathrm{H}$ NMR $\left(400 \mathrm{MHz}, \mathrm{CD}_{2} \mathrm{Cl}_{2}, 20^{\circ} \mathrm{C}\right): \delta_{\mathrm{H}} 0.49\left(\mathrm{~d}, 3 \mathrm{H},{ }^{3} J_{\mathrm{HH}}=6.4 \mathrm{~Hz}, \mathrm{CH}_{3}\right), 1.18\left(\mathrm{~d}, 3 \mathrm{H}^{3}{ }^{3} \mathrm{HH}=6.8 \mathrm{~Hz}, \mathrm{CH}_{3}\right), 2.35\left(\mathrm{~m}, 2 \mathrm{H}, \mathrm{CH}_{2}\right), 2.85$ (m, 4H, $\left.\mathrm{CH}_{2}\right), 3.73(\mathrm{~m}, 1 \mathrm{H}, \mathrm{CH}), 3.92(\mathrm{~m}, 1 \mathrm{H}, \mathrm{CH}) 7.3-7.9(20 \mathrm{H}, \mathrm{Ph}) \mathrm{ppm}$.

${ }^{13} \mathrm{C}\left\{{ }^{1} \mathrm{H}\right\}$ NMR $\left(100 \mathrm{MHz}, \mathrm{CD}_{2} \mathrm{Cl}_{2}, 20^{\circ} \mathrm{C}\right): \delta_{\mathrm{C}} 14.9\left(\mathrm{~s}, \mathrm{CH}_{2}\left(\mathrm{CH}_{2}\right)_{2}\right.$, cyclic carbone), 20.8 (br, $\left.\mathrm{CH}\left(\mathrm{CH}_{3}\right)_{2}\right), 23.9$ (second order triplet, $\mathrm{CH}_{2}\left(\mathrm{CH}_{2}\right)_{2}$, cyclic carbone), $27.9\left(\mathrm{~d},{ }^{3} \mathrm{JPC}=15 \mathrm{~Hz}, \mathrm{CH}\left(\mathrm{CH}_{3}\right)_{2}\right), 54.6\left(\mathrm{~d},{ }^{2} \mathrm{JPC}=24 \mathrm{~Hz}, \mathrm{CH}\left(\mathrm{CH}_{3}\right)_{2}\right), 62.8\left(\mathrm{~d},{ }^{2} \mathrm{JPC}=15 \mathrm{~Hz}, \mathrm{CH}\left(\mathrm{CH}_{3}\right)_{2}\right)$, 66.7 ( $\left.\mathrm{m}, \mathrm{C}_{\text {(carbone) })}\right), 131.5$ - $132.6\left(\mathrm{~m}, \mathrm{C}_{1}-\mathrm{C}_{4}\right.$, $\mathrm{Ph}$ of cyclic carbone) $\mathrm{ppm}$.

${ }^{31} \mathrm{P}\left\{{ }^{1} \mathrm{H}\right\}$ NMR $\left(161 \mathrm{MHz}, \mathrm{CD}_{2} \mathrm{Cl}_{2}, 20^{\circ} \mathrm{C}\right): \delta \mathrm{P} 19.1$ (second order doublet, $\mathrm{P}_{\text {carbone) }}, 351.5$ (second order triplet, $\left.\mathrm{P}_{\text {central }}\right) \mathrm{ppm}$.

$\left[\mathrm{Cy}_{2} \mathrm{NP}\left(\mathrm{C}\left(\mathrm{PPh}_{3}\right)_{2}\right)\right]^{2+}, \mathbf{3 c}^{2+}: 1.0 \mathrm{~g}(1.22 \mathrm{mmol})$ of $[\mathbf{2 c}][\mathrm{Cl}]$ and 2.1 equiv of $\mathrm{AlCl}_{3}$ or $\mathrm{Na}\left[\mathrm{BAr}_{4}^{\mathrm{f}}\right]$. Yield $0.81 \mathrm{~g}(61 \%)$ as $\mathrm{AlCl}_{4}^{-}$salt and $^{-}$ $1.78 \mathrm{~g}(59 \%)$ as $\left[\mathrm{BAr}_{4}^{\mathrm{f}}\right]^{-}$salt.

${ }^{1} \mathrm{H}$ NMR (400 MHz, $\mathrm{CD}_{2} \mathrm{Cl}_{2}, 20^{\circ} \mathrm{C}$ ): $\delta_{\mathrm{H}}$ 0.47-1.72 (br. m, 2H, $\mathrm{CH}_{2}-\mathrm{Cy}$ ), 3.36 (br, 1H, CH-Cy), 3.53 (br, 1H, CH-Cy), 7.3-7.9 (30H, $\mathrm{Ph}) \mathrm{ppm}$.

${ }^{13} \mathrm{C}\left\{{ }^{1} \mathrm{H}\right\}$ NMR (400 MHz, CD2Cl2, 20 ${ }^{\circ} \mathrm{C}$ ): $\delta_{\mathrm{C}} 23.7$ (s, $\delta$ - $\mathrm{CH}_{2}-\mathrm{Cy}$ ), 24.4 (s, $\left.\delta-C \mathrm{H}_{2}-\mathrm{Cy}\right), 25.0\left(\mathrm{~s}, \gamma-\mathrm{CH}_{2}-\mathrm{Cy}\right), 26.2\left(\mathrm{~s}, \gamma-C \mathrm{H}_{2}-\mathrm{Cy}\right), 30.9$

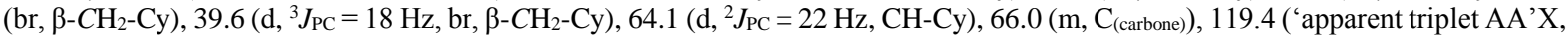
${ }^{1} \mathrm{~J}_{\mathrm{PC}}+{ }^{3} \mathrm{~J}_{\mathrm{PC}}=94 \mathrm{MHz}$, ipso-C, Ph of $\left.\mathrm{C}\left(\mathrm{PPh}_{3}\right)_{2}\right), 130.9\left(p-\mathrm{C}, \mathrm{Ph}\right.$ of $\left.\mathrm{C}\left(\mathrm{PPh}_{3}\right)_{2}\right), 133.8\left(\mathrm{t},{ }^{3} \mathrm{~J}_{\mathrm{PC}}=5.8 \mathrm{~Hz}, o-\mathrm{C}, \mathrm{Ph}\right.$ of $\left.\mathrm{C}\left(\mathrm{PPh}_{3}\right)_{2}\right), 137.7(m-\mathrm{C}$, $\mathrm{Ph}$ of $\left.\mathrm{C}\left(\mathrm{PPh}_{3}\right)_{2}\right) \mathrm{ppm}$.

${ }^{31} \mathrm{P}\left\{{ }^{1} \mathrm{H}\right\}$ NMR $\left(161 \mathrm{MHz}, \mathrm{CD}_{2} \mathrm{Cl}_{2}, 20^{\circ} \mathrm{C}\right): \delta_{\mathrm{P}} 26.0$ (second order doublet, $\mathrm{P}_{\text {carbone }}$ ), 360.4 (second order triplet, $\mathrm{P}_{\text {central }}$ ) ppm. Counterions:

$\mathrm{AlCl}_{4}:{ }^{27} \mathrm{Al} \mathrm{NMR}\left(104 \mathrm{MHz}, \mathrm{CD}_{2} \mathrm{Cl}_{2}, 20^{\circ} \mathrm{C}\right): \delta_{\mathrm{Al}} 106 \mathrm{ppm}$.

[BAr $\left.{ }_{4}\right]^{-}:{ }^{1} \mathrm{H}$ NMR $\left(400 \mathrm{MHz}, \mathrm{CD}_{2} \mathrm{Cl}_{2}, 20^{\circ} \mathrm{C}\right): \delta_{\mathrm{H}} 7.3-7.9(24 \mathrm{H}, \mathrm{Ph}) \mathrm{ppm} .{ }^{13} \mathrm{C}\left\{{ }^{1} \mathrm{H}\right\} \mathrm{NMR}\left(100 \mathrm{MHz}, \mathrm{CD}_{2} \mathrm{Cl}_{2}, 20{ }^{\circ} \mathrm{C}\right): \delta_{\mathrm{C}} 117.5(p-\mathrm{C})$, $124.6\left(\mathrm{q},{ }^{1} \mathrm{~J}_{\mathrm{CF}}=272 \mathrm{~Hz}, \mathrm{CF}_{3}\right), 128.9\left(\mathrm{q},{ }^{2} \mathrm{~J}_{\mathrm{CF}}=35 \mathrm{~Hz}, m-\mathrm{C}\right), 137.1(o-\mathrm{C}), 161.8\left(\mathrm{q},{ }^{1} \mathrm{~J}_{\mathrm{CB}}=50 \mathrm{~Hz}\right.$, ipso-C) ppm. ${ }^{11} \mathrm{~B}\left\{{ }^{1} \mathrm{H}\right\} \mathrm{NMR}(161$ $\left.\mathrm{MHz}, \mathrm{CD}_{2} \mathrm{Cl}_{2}, 20^{\circ} \mathrm{C}\right): \delta_{\mathrm{B}}-7.6 .{ }^{19} \mathrm{~F}\left\{{ }^{1} \mathrm{H}\right\} \mathrm{NMR}\left(376 \mathrm{MHz}, \mathrm{CD}_{2} \mathrm{Cl}_{2}, 20^{\circ} \mathrm{C}\right): \delta_{\mathrm{F}}-62.8 \mathrm{ppm}$.

Reactivity of [2a]Cl towards different sources of anions $\left(\mathrm{MOTf}\left(\mathrm{Tf}=\mathrm{O}_{2} \mathrm{SCF}_{3}\right), \mathrm{MOCl}_{4}, \mathrm{MBF}_{4}, \mathrm{MPF}_{6}, \mathrm{MSbF}_{6}, \mathrm{Na}\left[\mathrm{BAr}_{4}\right](\mathrm{M}=\right.$ $\mathrm{Na}$ or $\mathrm{Ag} ; \mathrm{Ar}=\mathrm{Ph}$ or 3,5- $\left.\mathrm{Cl}_{2}-\mathrm{C}_{6} \mathrm{H}_{3}\left(\mathrm{Ar}^{\mathrm{Cl}}\right)\right)$ : In a typical reaction $0.01 \mathrm{~g}(0.0135 \mathrm{mmol})$ of [2a]Cl was dissolved in a J. Young NMR tube using about $1 \mathrm{ml}$ of DCM followed by the addition of $2.1 \mathrm{eq}$ of an anion source. The reaction mixture was left to react for about $6 \mathrm{~h}$ by continuous rotation of the NMR tube and the reaction progress was followed by ${ }^{31} \mathrm{P} \mathrm{NMR}$ spectroscopy. Apart from $\mathrm{Na}$ [BAr ${ }^{\mathrm{Cl}} 4$ ], the use of all other Na-anion sources did not result in the P-Cl bond cleavage as the presence of the starting $\mathbf{2 a}^{+}$monocation was always evident (the use of $\mathrm{NaSbF}_{6}$ resulted in less than $10 \%$ conversion to the target dication). On the other hand the use of $\mathrm{Ag}$-salts resulted in cleavage of the $\mathrm{P}-\mathrm{Cl}$ bond and formation of multiple unidentified products except for $\mathrm{Ag}\left[\mathrm{SbF}_{6}\right]$. Then, this reaction was repeated on a preparatory scale using only $\mathrm{Ag}\left[\mathrm{SbF}_{6}\right]$ and $\mathrm{Na}\left[\mathrm{BAr}^{\mathrm{Cl}}{ }_{4}\right]$ according to the synthetic procedure for the target dications outline in this work (see above). As the multinuclear NMR for $\mathbf{3 a}^{\mathbf{2 +}}$ was virtually identical regardless of the nature of the counterion we only report the NMR data regarding the anions.

$\left[{ }^{i} \mathrm{Pr}_{2} \mathrm{NP}\left(\mathrm{C}\left(\mathrm{PPh}_{3}\right)_{2}\right)\right]^{2+}, \mathbf{3 a}^{2+}: 1.0 \mathrm{~g}(1.35 \mathrm{mmol})$ of $[\mathbf{2 a}][\mathrm{Cl}]$ and 2.1 equiv of $\mathrm{Ag}\left[\mathrm{SbF}_{6}\right]$ or $\mathrm{Na}\left[\mathrm{BAr}^{\mathrm{Cl}}{ }_{4}\right]$. Yield $0.79 \mathrm{~g}(51 \%)$ as $\left[\mathrm{SbF}_{6}\right]^{-} \mathrm{salt}^{2}$ (white solid) and $1.42 \mathrm{~g}(58 \%)$ as $\left[\mathrm{BAr}^{\mathrm{Cl}}\right]^{-}$salt (yellow solid).

$\left[\mathrm{BAr}^{\mathrm{Cl}} 4\right]^{-1}:{ }^{1} \mathrm{H}$ NMR $\left(400 \mathrm{MHz}, \mathrm{CD}_{2} \mathrm{Cl}_{2}, 20^{\circ} \mathrm{C}\right) \delta_{\mathrm{H}} 7.0-7.5(\mathrm{Ph}, 24 \mathrm{H}) \mathrm{ppm} .{ }^{13} \mathrm{C}\left\{{ }^{1} \mathrm{H}\right\} \mathrm{NMR}\left(100 \mathrm{MHz}, \mathrm{CD}_{2} \mathrm{Cl}_{2}, 20{ }^{\circ} \mathrm{C}\right): 123.1(p-\mathrm{C}), 133.5$ $(o-\mathrm{C}), 133.7(m-\mathrm{C}) 164.7\left(\mathrm{q},{ }^{1} \mathrm{~J}_{\mathrm{CB}}=50 \mathrm{~Hz}\right.$, ipso-C) ppm. ${ }^{11} \mathrm{~B}\left\{{ }^{1} \mathrm{H}\right\}\left(161 \mathrm{MHz}, \mathrm{CD}_{2} \mathrm{Cl}_{2}, 20{ }^{\circ} \mathrm{C}\right): \delta_{\mathrm{B}}-6.9 \mathrm{ppm}$. 
Crystallographic methods: Single crystals were mounted on quartz fiber and the X-ray intensity data were collected at 103(2) K (150.0(1) K for [3a] $\left[\mathrm{BAr}_{4}^{\mathrm{f}}\right]_{2}$ ) on a Bruker X8 APEX (Bruker Kappa APEX II for [3a] $\left[\mathrm{BAr}_{4}^{\mathrm{f}}\right]_{2}$ ) system, using Mo Ka radiation, with the SMART suite of programs. ${ }^{25}$ Data were processed and corrected for Lorentz and polarization effects with SAINT ${ }^{26}$ (DENZO \& COLLECT for $[3 \mathbf{3 a}]\left[\mathrm{BAr}_{4}^{\mathrm{f}}\right]_{2}$ ) and for absorption effects with SADABS $\left.{ }^{27}\left(\mathrm{DENZO} / \mathrm{SCALEPACK}^{28} \text { for [3a][BAr }{ }_{4}^{\mathrm{f}}\right]_{2}\right)$. Structural solution and refinement were carried out with the SHELXTL suite of programs. ${ }^{29}$ The structure was solved by direct method and refined for all data by full-matrix least-squares methods on $F^{2}$. All non-hydrogen atoms were subjected to anisotropic refinement. The hydrogen atoms were generated geometrically and allowed to ride on their respective parent atoms; they were assigned appropriate isotopic thermal parameters.

Crystallographic data for [2c] [BAr $\left.{ }_{4}^{\mathrm{f}}\right]: \mathrm{C}_{81} \mathrm{H}_{64} \mathrm{BClF}_{24} \mathrm{NP}_{3}, \mathrm{Mr} 1646.50$, triclinic, $\mathrm{P}_{1}, \mathrm{a}=12.2522(11), \mathrm{b}=16.1257(11)$, and $\mathrm{c}=$ 21.1731(18) $\AA, \alpha=110.232(2), \beta=103.504(2)$, and $\gamma=96.434(2)^{\circ}, \mathrm{V}=3730.5(5) \AA^{3}, Z=2, \rho c=1.466 \mathrm{gcm}^{-3}, \mathrm{~T}=103(2) \mathrm{K}, \lambda=$ $0.71073 \AA ; 58521$ reflections collected, 14630 independent [Rint $=5.63 \%$ ], which were used in all calculations; R1 $=0.0547, w R 2$ $=0.1521$ for $\mathrm{I}>2 \sigma(\mathrm{I})$, and $\mathrm{R} 1=0.0780, \mathrm{wR} 2=0.1827$ for all unique reflections; max and min residual electron densities $1.020 \mathrm{e} / \AA^{3}$ and - $1.049 \mathrm{e} / \AA^{3}$. CCDC: 1040919 .

Crystallographic data for [3a] $\left[\mathrm{SbF}_{6}\right]_{2}: \mathrm{C}_{44} \mathrm{H}_{46} \mathrm{Cl}_{2} \mathrm{~F}_{12} \mathrm{NP}_{3} \mathrm{Sb}_{2}$, Mr 1224.13, monoclinic, $\mathrm{P}_{1}, \mathrm{a}=11.180(8), \mathrm{b}=19.337(12)$ and $\mathrm{c}=$ 24.324(16) $\AA, \alpha=90.00, \beta=92.114(3)$ and $\gamma=90.00^{\circ}, \mathrm{V}=5254.7(6) \AA^{3}, \mathrm{Z}=4, \rho \mathrm{c}=1.547 \mathrm{gcm}^{-3}, \mathrm{~T}=103(2) \mathrm{K}, \lambda=0.71073 \AA ; 62748$ reflections collected, 13065 independent $[\mathrm{Rint}=12.70 \%$ ] which were used in all calculations; $\mathrm{R} 1=0.0964$, wR2 $=0.2769$ for $\mathrm{I}>2 \sigma(\mathrm{I})$; and $\mathrm{R} 1=0.1945$, wR2 $=0.3420$ for all unique reflections; max and min residual electron densities 3.589 and $-2.343 \mathrm{e} / \AA^{3}$. CCDC: 1040921.

Crystallographic data for [3a][BAr $\left.{ }_{4}^{\mathrm{f}}\right]_{2}: \mathrm{C}_{107} \mathrm{H}_{68} \mathrm{~B}_{2} \mathrm{~F}_{48} \mathrm{NP}_{3}$, Mr 2394.15, triclinic, $\mathrm{P}-1, \mathrm{a}=13.3889(2), \mathrm{b}=14.9027(3), \mathrm{c}=26.9846(4)$ $\AA, \alpha=78.9290(7), \beta=88.785(1)$ and $\gamma=86.024(1)^{\circ}, \mathrm{V}=5271.17(15) \AA^{3}, \mathrm{Z}=2, \rho \mathrm{c}=1.508 \mathrm{gcm}^{-3}, \mathrm{~T}=150.0(1) \mathrm{K}, \lambda=0.71069 \AA$; 71049 reflections collected, 23693 independent [Rint $=5.45 \%$ ], which were used in all calculations; $R 1=0.0752$, $w R 2=0.1714$ for $\mathrm{I}>2 \sigma(\mathrm{I})$ : $\max$ and min residual electron densities $0.681(0.062) \mathrm{e} / \AA^{3}$ and $-0.474(0.062) \mathrm{e} / \AA^{3}$. CCDC: 1404965 .

Crystallographic data for $[3 \mathrm{c}]\left[\mathrm{AlCl}_{4}\right]_{2}: \mathrm{C}_{110} \mathrm{H}_{113} \mathrm{Al}_{4} \mathrm{Cl}_{16} \mathrm{~F}_{4} \mathrm{~N}_{2} \mathrm{P}_{6}, \mathrm{Mr} 2399.96$, monoclinic, $\mathrm{P}_{21} / \mathrm{c}, \mathrm{a}=18.0978(8), \mathrm{b}=34.1490(13)$ and c $=19.2540(7) \AA, \alpha=90, \beta=103.9510(10)$ and $\gamma=90^{\circ}, \mathrm{V}=11548.4(8) \AA^{3}, \mathrm{Z}=4, \rho c=1.380 \mathrm{gcm}^{-3}, \mathrm{~T}=103(2) \mathrm{K}, \lambda=0.71073 \AA$; 92486 reflections collected, 30787 independent $[$ Rint $=7.12 \%$ ], which were used in all calculations; $R 1=0.0570$, wR2 $=0.1318$ for $\mathrm{I}>2 \sigma(\mathrm{I})$, and $\mathrm{R} 1=0.1171, \mathrm{wR} 2=0.1796$ for all unique reflections; $\max$ and min residual electron densities $0.872 \mathrm{e} / \AA^{3}$ and -1.157 $\mathrm{e} / \AA^{3}$. CCDC: 1040920 .

Solid state NMR: ${ }^{31} \mathrm{P}$ cross-polarization (CP) / magic angle spinning (MAS) NMR data were acquired on a Jeol Delta NMR spectrometer with a $9.4 \mathrm{~T}$ magnet. Typically 320 scans were acquired using $5.0 \mathrm{~ms} \mathrm{CP}$ contact times, and 15 repetitions times. The chemical shift scale was referenced against ammonium dihydrogenphosphate. Each compound was acquired at $5 \mathrm{kHz}, 9 \mathrm{kHz}$ and 11 $\mathrm{kHz}$ sample rotation frequencies, allowing for the determination of peaks at the isotropic chemical shifts and spinning sidebands.

Computational methods: Calculations were carried out with the Gaussian09 package $^{30}$ and all structures were optimized at the DFT level by means of the B3PW91 functional. ${ }^{31}$ The 6-31G(d) basis set was applied for all atoms. Geometries optimizations were performed without constraints, except for $3 \mathbf{e}_{\mathrm{p}}{ }^{2+}, \mathbf{3} \mathbf{e}^{2+}$ and $\mathbf{3} \mathbf{e}^{2+}$, for which the P-C-P-N and C-P-N-H dihedral angles were fixed at $0^{\circ}$ and $0^{\circ}\left(\mathbf{3 e}_{\mathrm{p}}{ }^{2+}\right), \pm 90^{\circ}$ and $0^{\circ}\left(\mathbf{3 e}^{2+}\right)$, and $0^{\circ}$ and $\pm 90^{\circ}\left(\mathbf{3 e}_{\mathbf{N}}{ }^{2+}\right)$. Final energy calculations at the B3PW91 level associated with the 6$311+\mathrm{G}(\mathrm{d}, \mathrm{p})$ basis set have been achieved on the B3PW91/6-31G(d) geometries. To get accurate geometries, the SCF convergence criterion was systematically tightened to $10^{-8}$ au, and the force minimizations were carried out until the rms force became smaller that (at least) $1 \times 10^{-5}$ au. Electronic structures obtained at the B3PW91/6-311+G(d,p)//B3PW91/6-31G(d) level were explored by means of natural bond order (NBO) analysis ${ }^{18}$ using the NBO6 program. ${ }^{32} \mathrm{NBO}$ analysis gives the atomic charges through natural population analysis (NPA). The $\pi$-electron population is obtained from the occupancy of the $\mathrm{p}_{\pi}$ natural atomic orbitals. ${ }^{33}$ It was also used to interpret the wavefunction of the systems in terms of natural localized bond orbitals, to study bond polarization and to evaluate the relative contribution of the $\mathrm{C}=\mathrm{P}-\mathrm{N}$ and $\mathrm{C}-\mathrm{P}=\mathrm{N}$ resonance structures by means of natural resonance theory (NRT). ${ }^{19}$ Second-order perturbation theory is used to estimate the second-order interaction energy $(\mathrm{E}(2))$ associated with two-electron donor-acceptor orbital interactions

\section{ACKNOWLEDGMENT}

We thank A*STAR (grant \# 1220703062) for the financial support. Computational work was performed using HPC resources from GENCI-CINES/IDRIS (Grant 2014-x086894).

\section{REFERENCES}

(1) See, for example: (a) Fleming, S.; Lupton, M. K.; Jekot, K. Inorg. Chem. 1972, 11, 2534. (b) Maryanoff, B. E.; Hutchins, R. O. J. Org. Chem. 1972, 37, 3475. (c) Cowley, A. H.; Kemp, R. A. Chem. Rev. 1985, 85, 367. (d) Gudat, D. Coord. Chem. Rev. 1997, 163, 71. (e) Burford, N.; Clyburne, J. A. C.; Losier, P.; Parks, T. M.; Cameron, T. S.; Richardson, J. F. Phosphorus, Sulfur Silicon Relat. Elem. 1994, 93, 301.

(2) See for example: (a) Caputo, C. A.; Jennings, M. C.; Tuononen, H. M.; Jones, N. D. Organometallics 2009, 28, 990. (b) Foerster, D.; Nickolaus, J.; Nieger, M.; Benko, Z.; Ehlers, A. W.; Gudat, D. Inorg. Chem. 2013, 52, 7699. (c) Pan, B.; Xu, Z.; Bezpalko, M. W.; Foxman, B. M.; Thomas, C. M. Inorg. Chem. 2012, 51, 4170. (d) Rosenberg, L. Coord. Chem. Rev. 2012, 256, 606. (e) Bezpalko, M. W.; Foxman, B. M.; Thomas, C. M. Inorg. Chem. 2015, DOI: 10.1021/acs.inorgchem.5b01363.

(3) Coordinative saturation is referred to the absence of formally empty p orbitals on the central P.

(4) (a) Petuškova, J.; Patil, M.; Holle, S.; Lehmann, C. W.; Thiel, W.; Alcarazo, M. J. Am. Chem. Soc. 2011, 133, 20758. (b) Weigand, J. J.; Feldmann, K.; Henne, F. D. J. Am. Chem. Soc. 2010, 132, 16321.

(5) (a) Toner, R.; Öxler, F.; Neumüller, B.; Petz, W.; Frenking, G. Angew. Chem. Int. Ed. 2006, 45, 8038. (b) Tonner, R.; Frenking, G. Angew. Chem. Int. Ed. 2007, 46, 8695. (c) Deshmukh, M. M.; Gadre, S. R.; Tonner, R.; Frenking, G. Phys. Chem. Chem. Phys. 2008, 10, 2298. (d) Tonner, R.; Frenking, G. Chem. Eur. J. 2008, 14, 3260. (e) Takagi, N.; Shimizu, T.; Frenking, G. Chem. Eur. J. 2009, 15, 8593. (f) Frenking, G.; Tonner, R. Pure Appl. Chem. 2009, 81, 597. (g) Takagi, N.; Shimizu, T.; Frenking, G. Chem. Eur. J. 2009, 15, 3448. (h) Tonner, R.; Frenking, G. Chem. Eur. J. 2008, 14, 3273. (i) Frenking, G. ; Tonner, R.; Klein, S.; Takagi, N.; 
Shimizu, T.; Krapp, A.; Pandeyc K. K.; Parameswaran, P. Chem. Soc. Rev. 2014, 43, 5106. (j) Petz, W. Coord. Chem. Rev. 2015, 291, 1.

(6) (a) Inés, B.; Patil, M.; Carreras, J.; Goddard, R.; Thiel, W.; Alcarazo, M. Angew. Chem. Int. Ed. 2011, 50, 8400. (b) Khan, S.; Gopakumar, G.; Thiel, W.; Alcarazo, M. Angew. Chem. Int. Ed. 2013, 52, 5644. (c) Tay, M. Q. Y.; Lu, Y.; Ganguly, R.; Vidović, D. Angew. Chem. Int. Ed. 2013, 52, 3132. (d) Tay, M. Q. Y.; Lu, Y.; Ganguly, R.; Vidović, D. Chem.-Eur. J. 2014, 20, 6628. (e) Chen, W.-C.; Lee, C.-Y.; Lin, B.-C.; Hsu, Y.-C.; Shen, J.-S.; Hsu, C.-P.; Yap, G. P. A.; Ong, T.-G. J. Am. Chem. Soc. 2014, 136, 914. (f) Loh, Y. K.; Gurnani, C.; Ganguly, R.; Vidović, D. Inorg. Chem. 2015, 54, 3087. (g) Đorđević, N.; Tay, M. Q. Y.; Muthaiah, S.; Ganguly, R.; Dimić, D.; Vidović, D. Inorg. Chem. 2015, 54, 4180. (h) Gurani, C.; Đorđević, N.; Muthaiah, S.; Dimić, D.; Ganguly, R.; Petković, M.; Vidović, D. Chem. Commun. 2015, 51, 10762. (i) Tay, M. Q. Y.; Lu, Y.; Ganguly, R.; Frison, G.; Richard, L.; Vidović, D.; Charmichael, D. Phosphorus, Sulfur Silicon Relat. Elem. 2015, 190, 785. (j) Ilić, G.; Ganguly, R.; Petrović, M.; Vidović, D. Chem.-Eur. J. 2015, DOI: 10.1002/chem.201503922.

(7) (a) Ramirez, F.; Desai, N. B.; Hansen, B.; McKelvie, N. J. Am. Chem. Soc. 1961, 83, 3539. (b) Hardy, G. E.; Zink, J. I.; Kaska, W. C.; Baldwin, J. C. J. Am. Chem. Soc. 1978, 100, 8001. (c) Schubert, U.; Kappenstein, C.; Milewski-Mahrla, B.; Schmidbaur, H. Chem. Ber. 1981, 114, 3070.

(8) (a) Schmidbaur, H.; Costa, T.; Milewski-Mahrla, B.; Schubert, U. Angew. Chem. Int. Ed. 1980, 19, 555. (b) Marrot, S.; Kato, T.; Gornitzka, H.; Baceiredo, A. Angew. Chem. Int. Ed. 2006, 45, 2598. (c) Dyker, C. A. ; Lavallo, V. ; Donnadieu, B. ; Bertrand, G. Angew. Chem. Int. Ed. 2008, 47, 3206. (d) Morosaki, T.; Suzuki, T.; Wang, W.-W.; Nagase, S.; Fujii, T. Angew. Chem. Int. Ed. 2014, $53,9569$.

(9) (a) Xiong, Y.; Yao, S.; Tan, G.; Inoue, S.; Driess, M. J. Am. Chem. Soc. 2013, 135, 5004. (b) Li, Y.; Mondal, K. C.; Roesky, H. W.; Zhu, H.; Stollberg, P.; Herbst-Irmer, R.; Stalke, D.; Andrada, D. M. J. Am. Chem. Soc. 2013, 135, 12422. (c) Xiong, Y.; Yao, S.; Inoue, S.; Epping, J. D.; Driess, M. Angew. Chem. Int. Ed. 2013, 52, 7147.

(10) Azouri, M.; Andrieu, J.; Picquet, M.; Cattey, H. Inorg. Chem. 2009, 48, 1236.

(11) (a) Mitzel, N. W.; J. Chem. Soc., Dalton Trans. 1998, 3239. (b) Boag, N. M.; Guest, A. J. Acta Cryst. 2007, E63, o4606.

(12) With respect to the P-N bond distance observed for amine-stabilized phosphenium cations (see, for example: Burford, N.;

Losier, P.; Bakshi, P. K.; Cameron, T. S. Chem. Commun. 1996, 307.) and iminophosphanes (see, for example: (a) Niecke, E.; Gudat, D. Angew. Chem. Int. Ed. Engl. 1991, 30, 217. (b) Miqueu, K.; Sotiropoulos, J.-M.; Pfister-Guillouzo, G.; Rudzevich, V. L.; Gonitzka, H.; Lavallo, V.; Romanenko, V. D. Eur. J. Inorg. Chem. 2004, 2289.)

(13) The distance for a single P-C bond is normally found at $>1.8 \AA$ while the same distance for phosphaalkenes is found between 1.6-1.7 Å (Mathey, F. Angew. Chem. Int. Ed. 2003, 42, 1578).

(14) We purposely introduced 1 equiv of $\left[\mathrm{NEt}_{4}\right]\left[\mathrm{OCl}_{4}\right]$ in a DCM solution containing $[3 \mathbf{3 a}]\left[\mathrm{BAr}_{4}^{\mathrm{f}}\right]_{2}$ resulting in immediate reaction and formation of several unidentified products. Even though we were not able to separate/isolate/identify the products, this reaction provided additional evidence that $\mathbf{3} \mathbf{a}^{2+}$ (presumably the other synthesized dications, as well) was not indeed stable in presence in some of these anions we tested.

(15) (a) Tang, S.; Monot, J.; El-Hellani, A.; Michelet, B.; Guillot, R.; Bour, C.; Gandon, V. Chem. Eur. J. 2012, 18, 10239. (b) ElHellani, A.; Monot, J.; Guillot, R.; Bour, C.; Gandon, V. Inorg. Chem. 2013, 52, 506. (c) El-Hellani, A.; Monot, J.; Tang, S.; Guillot, R.; Bour, C.; Gandon, V. Inorg. Chem. 2013, 52, 11493. (c) Bour, C.; Monot, J.; Tang, S.; Guillot, R.; Farjon, J.; Gandon, V. Organometallics 2014, 33, 594 .

(16) It is worth nothing that all monocations are of white or off-white color.

(17) Alvarez, S. Dalton Trans. 2013, 42, 8617.

(18) (a) Glendening, E. D.; Landis, C. R.; Weinhold, F. WIREs Comput. Mol. Sci. 2012, 2, 1. (b) Landis, C. R.; Weinhold, F. The Chemical Bond: Fundamental Aspects of Chemical Bonding; Wiley-VCH, Weinheim, 2014.

(19) (a) Glendening, E. D.; Weinhold, F. J. Comput. Chem. 1998, 19, 595. (b) Glendening, E. D.; Weinhold, F. J. Comput. Chem. 1998, 19, 610. (c) Glendening, E. D.; Weinhold, F. J. Comput. Chem. 1998, 19, 628.

(20) Huheey, J. E.; Keiter, E. A.; Keiter R. L. Inorganic Chemistry - Principles of Structure and Reactivity, $4^{\text {th }}$ Ed., HarperCollins College Publishers, New York, 1993.

(21) (a) Marinetti, A.; Mathey, F. Organometallics 1982, 1, 1488. (b) Yao, S.; Brym, M.; van Wüllen, C.; Driess, M. Angew. Chem. Int. Ed. 2007, 46, 4159.(c) Ghadwal, R. S.; Azhakar, R.; Roesky, H. W.; Pröpper, K.; Dittrich, B.; Klein, S.; Frenking, G. J. Am. Chem. Soc. 2011, 133, 17552. (d) Ghadwal, R. S.; Azhakar, R.; Roesky, H. W.; Pröpper, K.; Dittrich, B.; Goedecke, C.; Frenking, G. Chem. Commun. 2012, 48, 8186. (e) Alvarez, M. A. ; García, M. E. ; García-Vivó, D.; Ramos, A.; Ruiz, M. A. Inorg. Chem. 2012, 51, 3698. (f) Doux, M.; Ricard, L.; Mathey, F.; Le Floch, P.; Mézailles, N. Eur. J. Inorg. Chem. 2003, 687. (g) Centofantim, L. F.; Parry, R. F. Inorg. Chem. 1973, 12, 1456. (h) Janzen, A. F.; Kruczynski, L. J. Can. J. Chem. 1979, 57, 1903. (i) Arduengo III, A. J.; Stewart, C. A.; Devidson, F.; Dixon, D. A.; Becker, J. Y.; Culley, S. A.; Mizen, M. B. J. Am. Chem. Soc. 1987, $109,627$.

(22) (a) Burn, M. J.; Fickes, M. G.; Hartwig, J. F.; Hollander, F. J.; Bergman, R. G. J. Am. Chem. Soc. 1993, 115, 5875. (b) Seifter, A.; Scheid, D.; Lintl, G.; Zessin, T. Chem. Eur. J. 2009, 15, 12114.

(23) Bentivegna, B.; Mariani, C. I.; Smith, J. R.; Ma, S.; Rheingold, A. L.; Brunker, T. J. Organometallics 2014, 33, 2820.

(24) Chaplin, A. B.; Weller, A. S. Eur. J. Inorg. Chem., 2010, 32, 5124.

(25) SMART version 5.628; Bruker AXS Inc.: Madison, WI, 2001

(26) SAINT+ version 6.22a; Bruker AXS Inc.: Madison, WI, 2001

(27) Otwinowski, Z.; Minor, W. Meth. Enzymol. 1997, 276, 307.

(28) Sheldrick, G. M. SADABS; 1996.

(29) SHELXTL version 5.1; Bruker AXS Inc.: Madison, WI, 1997

(30) Frisch, M. J.; Trucks, G. W.; Schlegel, H. B.; Scuseria, G. E.; Robb, M. A.; Cheeseman, J. R.; Scalmani, G.; Barone, V.; Mennucci, B.; Petersson, G. A.; Nakatsuji, H.; Caricato, M.; Li, X.; Hratchian, H. P.; Izmaylov, A. F.; Bloino, J.; Zheng, G.; Sonnenberg, J. L.; Hada, M.; Ehara, M.; Toyota, K.; Fukuda, R.; Hasegawa, J.; Ishida, M.; Nakajima, T.; Honda, Y.; Kitao, O.; Nakai, H.; Vreven, T.; Montgomery, Jr., J. A.; Peralta, J. E.; Ogliaro, F.; Bearpark, M.; Heyd, J. J.; Brothers, E.; Kudin, K. N.; Staroverov, V. N.; Kobayashi, R.; Normand, J.; Raghavachari, K.; Rendell, A.; Burant, J. C.; Iyengar, S. S.; Tomasi, J.; Cossi, M.; Rega, N.; Millam, J. M.; Klene, M.; Knox, J. E.; Cross, J. B.; Bakken, V.; Adamo, C.; Jaramillo, J.; Gomperts, R.; Stratmann, R. E.; Yazyev, O.; Austin, A. J.; Cammi, R.; Pomelli, C.; Ochterski, J. W.; Martin, R. L.; Morokuma, K.; Zakrzewski, V. G.; Voth, G. A.; Salvador, P.; Dannenberg, J. J.; Dapprich, S.; Daniels, A. D.; Farkas, Ö.; Foresman, J. B.; Ortiz, J. V.; Cioslowski, J.; Fox, D. J. Gaussian, Inc., Wallingford CT, 2010. Gaussian 09 (Revision B.01).

(31) (a) Becke, A. D. J. Chem. Phys. 1993, 98, 5648. (b) Perdew, J. P.; Wang, Y. Phys. Rev. B 1992, 45, 13244. 
(32) (a) Glendening, E. D.; Badenhoop, J. K.; Reed, A. E.; Carpenter, J. E.; Bohmann, J. A.; Morales, C. M.; Landis, C. R.; Weinhold, F. Theoretical Chemistry Institute, University of Wisconsin, Madison, 2013, NBO 6.0. (b) Glendening, E. D.; Landis, C. R.;. Weinhold, F J. Comp. Chem. 2013, 34, 1429.

(33) Huynh, H. V.; Frison, G. J. Org. Chem. 2013, 78, 328. 
Preparation, Structural Analysis and Reactivity Studies of Phosphenium Dications

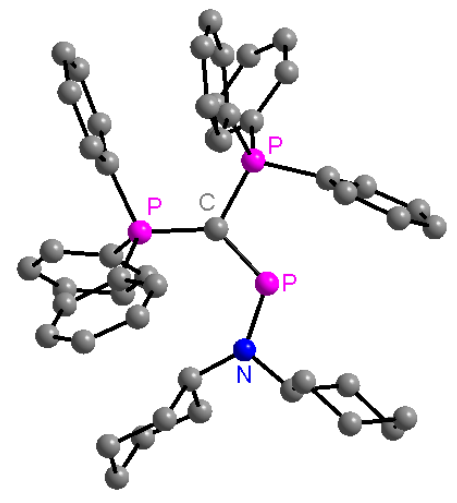

